BULLETIN Bulletin hispanique

HISPANIQUE Université Michel de Montaigne Bordeaux

$112-2 \mid 2010$

Varia

\title{
La construcción crítica de un Quevedo reaccionario
}

Alfonso Rey

\section{OpenEdition}

Journals

Edición electrónica

URL: http://journals.openedition.org/bulletinhispanique/1235

DOI: 10.4000/bulletinhispanique.1235

ISSN: 1775-3821

Editor

Presses universitaires de Bordeaux

Edición impresa

Fecha de publicación: 31 diciembre 2010

Paginación: 633-669

ISBN: 978-2-86781-709-0

ISSN: 0007-4640

Referencia electrónica

Alfonso Rey, "La construcción crítica de un Quevedo reaccionario », Bulletin hispanique [En línea], 112-2 | 2010, Publicado el 05 enero 2014, consultado el 13 noviembre 2019. URL : http:// journals.openedition.org/bulletinhispanique/1235; DOI : 10.4000/bulletinhispanique.1235 


\title{
La construcción crítica de un Quevedo reaccionario
}

\author{
Alfonso Rey \\ Universidad de Santiago de Compostela
}

Depuis le XVII siècle jusqu’à la première moitié du XX'e siècle, Quevedo a été jugé principalement comme un écrivain moraliste et satirique qui dénonce les abus, et aussi, dans de nombreux cas, comme un combattant contre la tyrannie, image renforcée au cours de l'époque romantique par l'exaltation de son opposition au Comte-Duc d'Olivares. Ces interprétations ont été maintenues pendant une grande partie de la première moitié $d u X X^{e}$ siècle, mais à partir du dernier tiers elles ont été remplacées par l'image de Quevedo comme un propagateur de ce que Marx et Engels avaient appelé "idéologie ", à savoir, un ensemble de sophismes visant à justifier l'oligarchie au pouvoir. Cette nouvelle interprétation devient utile car elle apporte une approche différente, mais elle semble endommagée par ses anachronismes. L'article conclut en proposant une lecture plus attentive des particularités linguistiques et historiques de Quevedo, ni romantique ni marxiste, fondée sur une réflexion historique et philologique plus rigoureuse.

Desde el siglo XVII hasta la primera mitad del siglo XX Quevedo fue valorado, fundamentalmente, como un tratadista moral y un satírico denunciador de abusos; también, en muchos casos, como un luchador contra el despotismo, imagen reforzada durante el romanticismo, que exaltó su oposición al Conde-Duque de Olivares. Tales interpretaciones se mantuvieron durante buena parte de la primera mitad del siglo XX, hasta que en su último tercio se consolidó una lectura de Quevedo como un propagador de lo que Marx y Engels denominaron ideología, es decir, falacias orientadas a justificar la oligarquía dominante. Esta nueva interpretación, útil en la medida en que aporta un enfoque diferente, parece dañada por sus anacronismos. El artículo concluye proponiendo una lectura más atenta a las peculiaridades de Quevedo, ni romántica ni marxista, sobre una base histórica y filológica más rigurosa.

Bulletin Hispanique, Tome 112, n 2 - décembre 2010 - p. 633 à 669. 
From the seventeenth Century to mid Twentieth Century, Quevedo was read as a moralist thinker and as a liberal and satirical writer who denounced abuse, as well as, in many cases, as a man who fought tyranny, mainly because of his alleged opposition to Count Duke of Olivares. This image was strengthened during the Romantic period, under the influence of scholars, on behalf of the idealistic portrayal of dramatic poets. During the first half of the Twentieth Century this interpretation basically remained unchanged. However, from the seventies onwards, there was an evolution due to the prevailing Marxist vague background among some French and Spanish scholars, which led to Quevedo being seen as an intellectual organico for the aristocracy. Such an interpretation, shared by many Quevedo specialists, has to be taken into consideration, although we need more data, a better understanding of his times and, which is most important, a closer reading of his works. The purpose of this article is of showing and correcting some of the most common errors and misinterpretations concerning this subject, and proposing a different philological approach.

Mots-clés: Quevedo - Réception - Pensée politique.

En realidad, Quevedo era muy reaccionario; creo que si hubiera vivido ahora sería franquista (Jorge Luis Borges) $^{1}$

S OBRE LA posibilidad de interpretar una obra literaria desde enfoques diferentes dijo Séneca que "no hay que admirarse de que de toda materia cada cual escoja lo que es adecuado a sus intereses; en el mismo prado el toro busca la hierba, el perro la liebre, la cigüeńa el lagarto» ${ }^{2}$. Cada época propende a valorar los clásicos en función de sus creencias y valores, los cuales condicionan la lectura de dos modos: el más visible, aceptando o rechazando las ideas y temas del escritor; el menos perceptible, pero frecuentemente más decisivo, orientando el significado de las palabras, a las que a veces se atribuyen referentes y connotaciones distintos de los que tuvieron. Quevedo fue un satírico, un tratadista y un polemista que

1. Cito por el libro de Julio Chiappini Borges y Quevedo, Corrientes, Zeus, 1991, p. 41, el cual sitúa las palabras de Borges, imprecisamente, en su prólogo al libro de Cansinos Assens El candelabro de los siete brazos.

2. «Non est quod mireris ex eadem materia suis quemque studiis apta colligere: in eodem prato bos herbam quaerit, canis leporem, ciconia lacertam», Epistola 108, 29. 
se pronunció sobre diversos aspectos de la vida social y política, de manera que está especialmente expuesto a ser leído en función de sentimientos e interpretaciones ajenos a su intención; además, se sirvió de expresiones e imágenes que han experimentado transformaciones semánticas de las que no siempre se es consciente, con el inevitable riesgo de anacronismo. Los cambios en la valoración ideológica de su obra así parecen confirmarlo.

\section{SigLO XVII}

Iniciado el siglo, Quevedo quiso proyectar una imagen de sí como humanista y erudito, pero prevaleció la de satírico, a juzgar por la reacciones de miedo y rechazo que suscitaron varias de sus obras. "Antes de cumplir veinticinco años ya había tropezado [...] con la rígida mentalidad de los censores», afirmó Crosby ${ }^{3}$. El responsable de la antÖología Flores de poetas ilustres, Pedro de Espinosa, retiró el soneto «Llegó a los pies de Cristo Madalena» y lo sustituyó por otro de Juan de Valdés que la burla quevediana contra los boticarios, apoyada en una irreverente alusión religiosa, justificaba el sacrificio de retirar los ejemplares impresos. Al parecer, similar suerte corrió la letrilla con el estribillo "Punto en boca», de la que no se imprimieron algunas estrofas. Pocos años después, hacia 1610, Quevedo fracasó en su intento de publicar los tres primeros Sueños, que fray Antolín Montojo informó en estos términos: «O el autor se ha propuesto burlarse de las Sagradas Escrituras, o las ignora, según su modo de hablar de ciertas cosas [...] El estilo es chabacano e imprudente y escandaloso sobremanera, y más propio de truhanes que de gente honrada y cristiana» ${ }^{5}$. Más imprecisas son las noticias acerca de la posible denegación, en 1617, del permiso para la representación de una comedia ${ }^{6}$. De estos tempranos y escuetos testimonios se deduce que pronto se desarrolló la fama de un Quevedo inclinado a la crítica de gobernantes y a la utilización de alusiones

3. "Más he querido atreverme que engañarme": Quevedo frente al dilema de hablar o callarse en los Sueños», La Perinola, 5, 2001, p. 109.

4. Para otros datos, véase Pablo Villar Amador, "Problemas de impresión en las Flores de poetas ilustres de España, de Pedro Espinosa», Boletín de la Real Academia Española, 71, 1991, pp. 353-81.

5. Cito por Luis Astrana Marín, Francisco de Quevedo, Obras completas. Prosa, Madrid, Aguilar, 1932, p. 129. Astrana también dio a conocer la censura de Antonio de Santo Domingo, pp. 129-30, que se limitó a aconsejar la eliminación de un párrafo poco respetuoso con personajes eclesiásticos.

6. Epistolario de Lope de Vega Carpio, Carta al Duque de Sessa de 6-11 octubre de 1617, edición de Agustín G. de Amezúa, Madrid, Aldus, 1941, III, p. 342. 
religiosas en contextos satíricos y burlescos, impresión que confirmarían -en su caso con una valoración muy negativa- las palabras de Matías de Novoa al afirmar que Olivares quiso atraer a Quevedo «o por miedo al genio satírico o por ver si, llamándole, iba y acertaba aquí con el agresor» ${ }^{7}$. Ese "genio satírico» resultó también díscolo, si se tiene en cuenta que El chitón de las tarabillas (1630), obra destinada a defender la política económica del gobierno frente a los ataques de alguno de sus detractores ${ }^{8}$, tropezó con la Inquisición, que, cinco meses después de impreso el libro, estimó que debía retirarse por ser «escandaloso, sedicioso, dogmatizante, injurioso y burlador de las cosas sagradas», además de «injurioso a los príncipes y cabezas", animado de "malicia redomada y disimulada»". No es descartable, por otra parte, que la defensa de las medidas económicas del Conde-Duque encubriera diversas críticas al mismo.

Las invectivas contra las obras de Quevedo ${ }^{10}$ también son representativas de un estado de ánimo que encierra una interpretación ideológica. En 1626 Francisco Morovelli de la Puebla dio a conocer la suya contra Política de Dios. En ¿1630? difundió Luis Pacheco de Narváez su Memorial denunciando al Tribunal de la Inquisición cuatro obras políticas y satíricas de Quevedo ${ }^{11}$, destacando su falta de respeto hacia reyes, privados, jueces y «los más

7. Historia de Felipe IV, rey de España, en Colección de documentos inéditos para la historia de España (CODOIN) 69, p. 73. Novoa hace este comentario a raíz de los libelos contra el gobierno que circularon tras la pérdida de la flota a manos de los holandeses. Y juzga así el escrito de Quevedo: «armó un librillo insolente en que satisfacía al Conde o respondía a las calumnias que le cargaban; indigno de juicio heroico, ni aun plebeyo».

8. En carta de mediados o finales de 1630 Lope de Vega comentó al duque de Sessa la impresión que le produjo El chitón de las tarabillas: «es verdaderísimo. Ojalá no lo fuera. Leyómele una tarde don Francisco de Aguilar en un coche en el río [...] En todo su discurso mira a cierto título que, a la cuenta, debía de murmurarlos con donaires». Lope califica el «papel» contraatacado por Quevedo como «lo más satírico y venenoso que se ha visto desde el principio del mundo, y bastante para matar a la persona culpada, que lo debió de ser mucho, pues dio tal ocasión"; Epistolario de Lope de Vega Carpio, IV, p. 142.

9. Archivo Histórico Nacional, Inquisición, legajo 4444, f. 27. Manuel Urí comentó este juicio en su edición de El chitón de las tarabillas, Madrid, Castalia, 1998, pp. 31-34. Mercedes agulló ofreció datos complementarios en "La edición madrileńa de El Chitón de las tarabillas», Voz y letra, 18, 2007, pp. 87-98.

10. Quedan fuera de mi consideración las invectivas literarias y personales porque, pese a conformar la imagen de Quevedo en su tiempo, no contienen los juicios de tipo político y social objeto del presente artículo.

11. Aurelio Valladares Regueiro comentó la respuesta de Quevedo en «La sátira quevedesca contra Luis Pacheco de Narváez", Sobre Quevedo y su época, Homenaje a Jesús Sepúlveda, Cuenca, Universidad de Castilla La Mancha, 2007, pp. 185-214. Y ofreció otros datos sobre la relación entre los dos escritores en el estudio que acompaña su edición de Peregrinos discursos y tardes bien empleadas, Pamplona, Eunsa, 2006. 


\section{LA CONSTRUCCIÓN CRÍTICA DE UN QUEVEDO REACCIONARIO}

principales fundamentos de nuestra religión sagrada y los mayores estados de la Iglesia ${ }^{12}$. En 1635 se imprimieron tres ataques muy pormenorizados: dos a cargo de Juan de Jáuregui -el Memorial al rey nuestro señor y la comedia El retraído- y otro, atribuido también a Pacheco de Narváez ${ }^{13}$, El Tribunal de la Justa Venganza, que insistía en pedir la intervención inquisitorial y gubernamental contra Quevedo. De 1640 datan los Peregrinos discursos $y$ tardes bien empleadas, pormenorizado alegato contra Politica de Dios. Aunque el conjunto de esas críticas es muy heterogéneo, puede considerarse representativa la de Juan Ponce de León cuando, después de solicitar la retirada y "perpetuo silencio» de Cuento de cuentos, advertía:

La religión viene a padecer agravio en los seglares, pues estudiando arte para ser agudos, aprenden de los libros de Quevedo sus satíricos dichos y escandalosos donaires. Todo lo cual es digno de reparo (si en ello se repara), temiendo que principios como éstos, en España, no sean pronósticos de los lastimosos sucesos que se vieron en Francia, de que se originaron muchas herejías, con que se halló cuidadosa la Iglesia en su remedio, pues en tiempo de Francisco Primero, rey de Francia, vivió en ella un hombre de cortas obligaciones llamado Francisco de Rabeles, el cual se preciaba de ser picante y maldiciente; y para tener materia en que ejercer su malicia, recogió en un libro cantidad de cuentos, novelas y donaires, en el cual hacía burla de los clérigos, de los religiosos, al modo que entre los italianos el Boccaccio. Los cuales cuentos, reducidos a un libro, con otros de Juan Maroto, compuestos en verso pastoril, ayudaron a los herejes en Francia al menosprecio y desestima de la religión, con lo cual se dispusieron los ánimos franceses para que a pocos lances se introdujese la común herejía y el menosprecio de la religión monástica ${ }^{14}$.

Las variantes paliativas que se observan en las diferentes fases redaccionales de los Sueños, el Buscón y Discurso de todos los diablos ${ }^{15}$ permiten ver el

12. En La astrea sáfica (1640), a raíz de la difusión del poema "Católica, sacra real majestad», atribuido a Quevedo, José Pellicer parafraseó el texto bíblico para recriminarlo en estos términos: «No murmures del rey en tu imaginación, ni en el secreto de tu aposento maldigas al rico, porque las aves del cielo llevarán tu voz y quien tiene alas parlará tu sentimiento».

13. Véanse los argumentos que expone Victoriano Roncero en el estudio preliminar de su edición de la citada obra, Pamplona, Eunsa, 2008.

14. Francisco de Quevedo, Obras completas. Prosa, edición de Astrana Marín, p. 657.

15. Sobre la autocensura en el Buscón, con su concreta incidencia en el texto, se ofrecen datos en el estudio preliminar de Las cuatro versiones del Buscón, ed. de Alfonso Rey et alii, Madrid, Consejo Superior de Investigaciones científicas, 2007, y en el de la edición crítica y facsímil de la edición príncipe (Zaragoza, Institución Fernando el Católico, 2010). Con respecto a los Sueños, véase la edición de James O. Crosby, Madrid, Castalia, 1993, y para 
peso de la autocensura en Quevedo, sentimiento que tuvo una expresa manifestación en 1631, cuando publicó la versión expurgada de Juguetes de la niñez. En su prólogo lamentó la ausencia de apoyos ${ }^{16}$, la abundancia de detractores y la pusilanimidad de sus propios editores: «Tanto ha podido el miedo de los impresores que me ha quitado el gusto que yo tenía de divulgar estas cosas, que me dejan ocupado en su disculpa, y con obligación a la penitencia de haberlas escrito ${ }^{17}$. Así se entiende que en 1632 , coincidiendo con la publicación del Índice de Zapata, «anticipándose a la táctica de sus antagonistas que iban a pedir para sus obras una condenación afrentosa que salpicase de lodo al autor, solicitó que los escritos impresos antes de 1630 fuesen recogidos» ${ }^{18}$.

En el prólogo "Al lector» de Las tres musas últimas castellanas (Madrid, 1670), Pedro de Aldrete comparó a su tío con «aquel fuerte varón Elezaro, que nos refiere el libro 2 de los Macabeos en el capítulo 6, que quiso más perder la vida que disimular». Tal vez convenga reducir el tono admirativo de tales palabras, pero sí merecen tenerse en cuenta otras en las que dice que, a propósito de "la averiguación de los fraudes de la Real Hacienda», «le ofrecieron cincuenta mil ducados porque disimulase o diese larga a los negocios. No lo quiso hacer. Consta por carta del Duque, escrita a Su Majestad, cuyo original tengo en mi poder, su fecha en 20 de mayo de 1617 y por esto padeció en su vida muchas persecuciones y granjeó muchos enemigos» ${ }^{19}$. Mención aparte debe hacerse de su detención en 1639 y posterior encarcelamiento en San Marcos de León. Entre otras causas posibles, el episodio guarda relación con unos "papeles» que se le confiscaron al escritor en el momento de su detención. A ellos se refirió

Discurso de todos los diablos, la de Miguel Marañón Ripoll, Madrid, Fundación Universitaria Española, 2005.

16. «Y digan y hagan lo que quisieren los Mecenas, que como nunca los he visto andar a cachetes con los murmuradores sobre si dijo o no dijo, y los veo muy pacíficos de amparo, desmentidos de todas las calumnias que hacen a sus encomendados, sin acordarse del libro del duelo, más he querido atreverme que engañarme. Hagan todos lo que quisieren de mi libro, pues yo he dicho lo que he querido de todos. Adiós, Mecenas, que me despido de dedicatoria». Véase, «Dedicatoria a ninguna persona de todas cuantas Dios crió en el mundo».

17. En el prólogo "A los que han leído y leyeren», que viene a continuación de la dedicatoria reproducida en la nota anterior. Otros aspectos de la actitud de Quevedo fueron analizados por Crosby en «Un grito de protesta, de desprecio y de independencia: Quevedo y los Juguetes de la niñez», Estudios de literatura española del Siglo de Oro dedicados a Elías L. Rivers, edición de Brian Dutton y Victoriano Roncero, Madrid, Castalia, 1992, pp. 99-104.

18. Pablo Jauralde, Francisco de Quevedo (1580-1645), Madrid, Castalia, 1998, p. 621.

19. Las tres musas últimas castellanas, Madrid, Imprenta Real, 1670 , f. $97-7 \mathrm{v}$ para las dos citas. Pocos datos ofrece Pablo de Tarsia en su Vida de don Francisco de Quevedo, Madrid, 1663. 
cuando pidió la libertad a Felipe IV, y a ellos aludió el monarca cuando, en mayo de 1643, solicitó un informe a José González y Juan Chumacero. Éste, en su respuesta al rey, aconseja retirar una sátira contra religiosos y unos cuadernos titulados Desengaños de la historia, a la vez que afirma no haber sido don Francisco «el autor de un romance, a cuya publicación se siguió el prenderle» ${ }^{20}$. Cualquiera que hubiese sido el desencadenante de la detención de Quevedo, parece claro que su actividad literaria fue tenida en cuenta por parte de quienes entendieron en su prisión y posterior liberación.

No deben quedar sin una rápida mención, aunque sean menos significativos para nuestro propósito, los elogios dispensados a Quevedo por sus contemporáneos ${ }^{21}$. Lope de Vega alabó su cultura y talento estilístico en diversos lugares de La Circe, Laurel de Apolo y Tomé de Burguillos, cualidades también reconocidas por Cervantes en la Adjunta del Parnaso, por Gracián en el capítulo III, 12 de El Criticón y por González de Salas en sus comentarios a la edición de El Parnaso español. Con otro matiz, Juan Eusebio Nieremberg destacó su filiación estoica y moral. En el Hospital das Letras, de Manuel de Melo, prevalece la imagen del Quevedo erudito que intercambia opiniones con el propio autor, Boccalinni y Lipsio, pero también hay una referencia a sus ideas políticas, pues en el curso de su conversación explica que su prisión se debió a los comentarios que realizó en la casa del Duque de Medinaceli oponiéndose a la institución del privado y alabando la deposición del tirano ${ }^{22}$. Aunque de modo muy lacónico, se ofrece ahí la semblanza de un humanista que sabe interesarse por el problema del poder político, imagen que también se encuentra en Francisco Santos: «El mayor hombre que las edades conocieron, gran teólogo, gran filósofo, gran poeta, gran decidor de verdades: por eso fue amargo, porque dijo su sentir verdadero ${ }^{23}$.

Erudito, moralista, satírico mordaz en materia social y política, escritor irreverente en cuestiones relacionadas con los estados eclesiásticos: tal es la imagen que se tuvo de Quevedo en su siglo. Algunos investigadores tienden a creer que los protagonistas y testigos inmediatos de los hechos

20. Tomo los datos de Jauralde, Francisco de Quevedo (1580-1645), pp. 819-20.

21. Astrana Marín recogió diversos elogios en su edición de Quevedo, Obras completas, Verso, Madrid, Aguilar, 1932, pp. 945-73.

22. Francisco Manuel de Melo, Apologos dialogaes. Sigo la edición de 1721, Lisboa, Mathias Pereira da Silva y Joan Antunes Pedrozo. El diálogo Hospital das Letras es el apólogo cuarto, pp. 299-464 de la citada edición.

23. En el romance que precede a ese comentario, Quevedo es presentado fundamentalmente como un moralista y reformador de costumbres, mal entendido en su tiempo: «Aliéntate tú que escribes / verdades, y ten valor, / y el Cid consuélese al ver / que también Quevedo censurado se vio». Tomo ambas referencias de El no importa de España y la verdad en el potro, edición de Julio Rodríguez Puértolas, Londres, Tamesis Books, 1973, p. 157. 
históricos no tienen plena conciencia de los mismos, que su interpretación carece de hondura y que sólo quienes vienen después están en condiciones de otorgarles una significación más ajustada. La lectura de Quevedo que hicieron sus contemporáneos no cierra el paso a interpretaciones diferentes, pero probablemente constituye un error menospreciarla.

\section{SigLOS XVIII Y XIX}

Durante el siglo XVIII, cuando la literatura abarcaba todo el campo de las letras, incluidas las relacionadas con el pensamiento y la ciencia, existió bastante aprecio por el pensador Quevedo, por el autor de tratados teóricos. Tal predilección se entiende bien en el contexto del Teatro histórico crítico de la elocuencia española (1786-1794) de Antonio de Capmany y en la actitud de los ilustrados, que concibieron la literatura como instrumento de formación moral y política de los ciudadanos, especialmente cuando su estudio pasó a convertirse en «materia incluible en los programas de la Enseñanza Media y la Universidad ${ }^{24}$. Es bien conocida la admiración profesada por Torres de Villarroel, en cuyas Visiones y Visitas rinde un sostenido homenaje a Quevedo, de quien destaca, preferentemente, su faceta de escritor que corrige costumbres y satiriza a malos ministros, razones por las cuales estuvo "preso, desterrado y aborrecido». No desentona de esa interpretación la breve alusión a Quevedo que hace Forner en sus Exequias de la lengua castellana. Pese a sus diferencias en tantos órdenes de la vida, la Ilustración coincidió con el Barroco en poseer una concepción eminentemente didáctica de la literatura. Feijóo presentó su Teatro crítico universal como «Discursos varios en todo género de materias, para desengaño de errores comunes»; con parecido talante, Quevedo había titulado una de sus obras más conocidas como Sueños y discursos de verdades descubridoras de abusos, vicios y engaños en todos los oficios y estados del mundo.

Después de haber sido personaje literario en obras de Manuel de Melo y Joseph Hall ${ }^{25}$, Quevedo lo fue de modo más asiduo en manos de escritores

24. Leonardo Romero Tobar, «Entre 1898 y 1998: la historiografía de la literatura española», en Del 98 al 98. Literatura e historia literaria en el siglo XX hispánico, ed. de Víctor García Ruiz, Rosa Fernández Urtasun y David K. Herzberger, Pamplona, Universidad de Navarra, 1999, p. 29.

25. The Travels of Don Francisco de Quevedo through Terra Australis Incognita, Discovering the Laws, Customs, Manners, and Fashions of the South Indians. A Novel, Originally in Spanish, London, W. Grantham, 1684. La atribución a Joseph Hall no está exenta de dudas. 


\section{LA CONSTRUCCIÓN CRÍTICA DE UN QUEVEDO REACCIONARIO}

románticos ${ }^{26}$, que encontraron en su biografía y leyendas anejas fuente de inspiración para dramas históricos y folletines ${ }^{27}$. Convertido, según los casos, en caballero de capa y espada, amante platónico, galanteador, misógino, moralista o melancólico, fue también la antítesis del tirano Olivares, y probablemente éste es el rasgo más destacado de los dramas escritos por Escosura, Gil de Zárate, Florentino Sanz y Bretón de los Herreros, así como, ya en el siglo XX en El caballero de las espuelas de oro. Tal oposición al gobernante pervivió en los folletines de final de siglo, pues aunque los relatos de Orellana, San Martín y Fernández y González crearon un Quevedo de amores y estocadas, por decirlo con uno de los títulos más conocidos, en ellos seguía estando presente la habitual oposición entre el escritor y Olivares, con las consiguientes reflexiones políticas. La invención de un Quevedo liberal, fustigador de reyes y ministros, reposa en un ideal y unas convenciones gratas al siglo XIX, pero éstas encontraron apoyo en sus obras satíricas y morales, así como en la visión transmitida por los siglos anteriores.

No fueron totalmente ajenos a ese espíritu algunos eruditos. Basilio S. Castellanos leyó a Quevedo desde su mentalidad de liberal ilustrado que abomina de «los calabozos hediondos» de la Inquisición e identifica el progreso de España con las clases medias ${ }^{28}$. Consecuentemente, lo consideró «el escritor más filósofo, profundo y entendido del siglo XVII»

26. Entre los dramaturgos cabe mencionar a Patricio de la Escosura (La corte del Buen Retiro; Todos los muertos se vengan), Antonio Gil y Zárate (Un monarca y su privado), Florentino Sanz (Don Francisco de Quevedo), Manuel Bretón de los Herreros (¿Quién es ella?), Luis de Eguílaz (Cuando ahorcaron a Quevedo; Una broma de Quevedo), Luis Mariano de Larra (La pluma y la espada), Francisco Botella (Una noche y una aurora) y Narciso Serra (La boda de Quevedo); entre los narradores, Francisco Orellana (Quevedo, novela histórica), Manuel Fernández y González (Amores y estocadas) y Antonio de San Martín (El casamiento de Quevedo y el conde-duque de Olivares, así como otros cuatro relatos). Comenta estas y otras obras Germán de Patricio en «Recepción diacrónica de Quevedo: manipulador manipulado, símbolo colectivo", en prensa La Perinola, 15, 2011, que he consultado en http://people. virginia.edu/-gd9e/DePatricio. Otros aspectos de Quevedo como personaje teatral fueron abordados por Narciso Alonso Cortés, Quevedo en el teatro, y otras cosas, Valladolid, Colegio Santiago, 1930, y C. C. García Valdés, "Con otra mirada: Quevedo, personaje dramático», La Perinola, 8, 2004, pp. 171-85.

27. "Quevedo had been somewhat of a growth industry since Patricio de la Escosura made him a lead character in La Corte del Buen Retiro; following him, Quevedo appeared in numerous plays», señaló David Thatcher Gies, The Theatre in Nineteeth-Century Spain, Cambridge, University Press, 1994, p. 266.

28. Obras de don Francisco de Quevedo Villegas, Madrid, Establecimientos Tipográficos, II, 1843, p. 342. Castellanos situó a Quevedo en la clase media, «la que ha dado prez y gloria a nuestra nación", en contraste con la estéril ociosidad de los nobles, a quienes acudieron los reyes para gobernar sus estados. 
y, en consonancia con tal semblanza, destacó el Buscón por su denuncia de, entre otros aspectos, los malos funcionarios de justicia, la ignorancia de las clases acomodadas, los malos sacerdotes, la superstición popular y la brujería ${ }^{29}$. En 1852 y 1859 Aureliano Fernández-Guerra editó la prosa completa de Quevedo dividida en dos tomos. En el «Discurso preliminar» del primero destacó el sentido ético de Política de Dios y Marco Bruto, el carácter reformista de los Sueños y el filosófico de La Fortuna con seso y la hora de todos, a la vez que celebró el gracejo de las obras que denominó festivas; en el del segundo, alabó los tratados ascéticos y religiosos, «tesoro de enseñanza moral y política» a la vez que "galería de retratos de magnates y palaciegos, de predicadores afamados, de jueces, cronistas y poetas de la primera mitad del siglo XVII» ${ }^{30}$. Instrucción moral, patriotismo, pintura crítica de la sociedad y rebeldía frente al absolutismo son los rasgos que destaca el primer editor crítico de Quevedo, los mismos que poco después, 1859 , puso de relieve Juan Valera en su reseńa a la mencionada edición ${ }^{31}$. Ambos pareceres perduran en otros críticos de ese tiempo: tanto Cayetano Soler como Antonio Cánovas del Castillo vieron a Quevedo como un moralista, un censor literario y político, cuyas denuncias le acarrearon la pérdida de su libertad ${ }^{32}$.

Con mayor distancia emocional y planteamientos más técnicos, el francés Ernest Mérimée publicó en 1886 una vida y obra de Quevedo donde proyectó algunas opiniones similares en lo que atañe a la valoración ideológica de Quevedo: los Sueños le parecieron obras que deslizan de cuando en cuando "quelque vérité courageuse», si bien carentes de la profundidad de Rabelais y el atrevimiento de Voltaire; Política de Dios, un intento, a la manera de Bossuet o Montesquieu, de utilizar la religión como freno del despotismo. En esta obra y Marco Bruto vio el estudioso francés la manifestación de un «défenseur aussi hésitant de la liberté politique», juntamente con «amour de la justice» y «sympathie pour les misérables». Las limitaciones de Quevedo como tratadista político quedan compensadas, según Mérimée, por el hecho de que Quevedo mostró «avoir cru jusqu’au bout à la justice, à la vertu, au droit, fondements de la politique» ${ }^{33}$.

29. Véanse, respectivamente, las páginas 342, 357, 361, 364, 365-66 y 381.

30. A. Fernández-Guerra, Obras de don Francisco de Quevedo y Villegas, Madrid, Biblioteca de Autores Españoles 48, 1859, p. XV.

31. Obras completas, Madrid, Aguilar, 1961, II, p. 1444.

32. Véanse, respectivamente, ¿Quién fue don Francisco de Quevedo? Estudio psicológico, Barcelona, 1899 y Bosquejo histórico de la Casa de Austria en España, Málaga, Algazara, 1892, pp. $286-87$ y 315 .

33. Essai sur la vie et les oeuvres de Francisco de Quevedo (1580-1645), Paris, Alphonse Picard, 1886, pp. 210, 237 y 240 para las tres citas. 
A la vez que comentaba los estudios de Fernández-Guerra y Mérimée, Pardo Bazán dio a conocer sus propias opiniones sobre Quevedo ${ }^{34}$, con algunas observaciones poco convencionales. Así, consideró que la misoginia quevediana sólo lo era apariencia, pues formaba parte de una crítica general de las costumbres, expresión de una actitud literaria culta más que de una frustración íntima ${ }^{35}$. En otra vertiente, entendió que la peculiaridad de Quevedo se debía a haber escrito «literatura de oposición» y sátiras que expresan «el común sentir del vulgo nacional» ${ }^{36}$. También Antonio Maura, con motivo del homenaje rendido a Mérimée por parte de la Real Academia Española, situó a Quevedo en una dimensión cultural europea:

no era el escritor más a propósito para desentrañar el espíritu castizo de la literatura espańola. Quevedo estuvo imbuido de la cultura humanista, moral, teológica y clásica, predominante dondequiera durante los primeros siglos de la Edad Moderna; no tenía el sello privativo de nuestro genio nacional. Quevedo hizo larga mansión en Italia [...] en donde tuvo absorbentes desvelos políticos y diplomáticos [...] Muy atrayente para el estudio y la admiración; pero inseguro guía para adentrarse en el centro espiritual de la gente espańola ${ }^{37}$.

Menéndez Pelayo no regateó a Quevedo el reconocimiento de su grandeza, pero también dejó patentes sus reticencias: no le entusiasmó su estilo y vio en su persona un genio tortuoso y anárquico, propenso a juicios y actuaciones extremadas. Tal vez con sus palabras propició la semblanza de un escritor de

34. En Hombres y mujeres de antaño. Semblanzas, Barcelona, Antonio López, [s. a.], pp. 7-97.

35. «En todo lo escrito por Quevedo contra las mujeres y el matrimonio hay, no obstante, más malicia que saña, más picante que amargo, más procacidad que fundado desprecio. Para la causa de los intereses de la mujer, tal cual hoy la entendemos, son quizá más temibles los serios y doctos tratados de Vives y Fray Luis de León, que las chuscadas, bufonerías y enormes licencias rabelasianas del poeta de cuatro ojos. Lo repito: las invectivas de Quevedo, aunque en apariencia dirigidas contra las mujeres, alcanzaban a toda la sociedad de su época, que nos aparece, vista al través de sus obras satíricas, corrompida hasta la médula, y, sobre todo, venal»; Hombres y mujeres de antaño, pp. 41-42.

36. Hombres y mujeres de antaño, p. 7. Cabe indicar que en un cuaderno de Chistes, chascos, chascarrillos y epigramas auténticos de don Francisco de Quevedo (cito por la edición de Madrid, El Olivo, 2007) se conserva la imagen de un Quevedo opositor, junto con otras semblanzas más chabacanas.

37. «Discurso [...] para honrar la memoria de [...] E. Mérimée», Boletín de la Real Academia Española, 11 (1924), pp. 150-51. 
comportamiento oscuro y pasiones inconfesadas ${ }^{38}$, parecer compartido por algunos comentaristas del siglo XX que llegaron a sugerir una relación entre su inestabilidad anímica y determinadas posiciones sociales y políticas ${ }^{39}$.

\section{Primera Mitad Del Siglo XX}

En un temprano manual de literatura española, James Fitzmaurice-Kelly, después de lamentar la artificiosidad estilística de Quevedo ("protestó del gongorismo, pero sustituyó una afectación por otra»), sintetizó así su ánimo satírico: «se apresuró a reírse de todo, para no tener que llorar». Como otros críticos del siglo XIX, el hispanista irlandés mostró mayor aprecio por los temas que por su plasmación literaria: «Hubiera podido ser grande como poeta o filósofo, como crítico o novelista, como teólogo u hombre de Estado: quiso serlo todo a la vez, y en el pecado llevó la penitencia» ${ }^{40}$. Su visión de Quevedo, muy lacónica, parece estar en deuda con las de FernándezGuerra y Mérimée ${ }^{41}$. Algo similar se podría decir de Julián Juderías, que se interesó preferentemente por las preocupaciones de Quevedo en torno a la monarquía, la tiranía, el privado, la guerra, los impuestos y la justicia. Destacó su voluntad de entender la política en términos éticos ${ }^{42}$, alabando «al escritor que diagnosticó de tan portentosa manera la enfermedad que padecía el organismo español», pese a que su estoicismo "a nada conduce [...] reńido con las aspiraciones de la vida moderna». Por los mismos años, y con argumentos similares, René Bouvier presentó a Quevedo como un "champion du passé», un heroico polemista "à la fois le plus violent et le plus courageux de l'Espagne du XVII siècle», dispuesto a transitar "vers un

38. «Ingenio [...] ciertamente grande, pero de los menos pulcros y de los más erráticos, vagabundos e indisciplinables», inclinado a "oscuras moralidades sentenciosas, a rasgos de la familia de los de Séneca, a tétricas agudezas, que convierten su estilo en una perenne danza de los muertos». Historia de las ideas estéticas en España, Madrid, CSIC, 1974, I, pp. 730 y 824, respectivamente.

39. Véase, por ejemplo, Enrique Tierno Galván, "Notas sobre el Barroco», Anales de la Universidad de Murcia, 1954-1955, pp. 125-29. O, en otro ámbito, la novela de Néstor Luján La cruz en la espada.

40. Historia de la literatura española, Madrid, Ruiz Hermanos, 1926. Ambas citas en p. 281.

41. Se podría recordar aquí el sucinto parecer expresado por Hermenegildo Giner de los Ríos en su Manual de Literatura nacional y extranjera, antigua y moderna, Madrid, Góngora Álvarez, 1909, donde afirma que Quevedo fue «acaso el más serio de nuestros pensadores, vestido con el ropaje alegre de la broma [...] enemigo del fraude» (pp. 169-70).

42. Don Francisco de Quevedo y Villegas. La época, el hombre, las doctrinas, Madrid, Establecimiento tipográfico de Jaime Ratés, 1922, p. 215-16 y 257. 
vieil idéal fossilisé, sur les anciens et rudes chemins», sin amilanarse ante el absolutismo y la Inquisición ${ }^{43}$. Más encendido se mostró Julio Cejador, como en el siguiente comentario sobre Política de Dios: «enseña a no justificar jamás la expropiación y el robo del territorio ajeno, el mentir y negar la palabra, el romper los juramentos sagrados y solemnes; que abomina las inicuas fórmulas de absolver toda vileza, tiranía y sacrilegio. Despliega Quevedo todas las galas de su fantasía al retratar con terrible pincel a los reyes comedores de pueblos» ${ }^{44}$. En parecida línea, el duque de Maura se preguntó cómo un «miembro devoto de varias cofradías piadosas satirizó despiadadamente a curas, frailes y monjas" y cómo "un aristócrata de nacimiento, caballero santiaguista, gustó de poner en la picota a los nobles que, según él, no merecían serlo» ${ }^{45}$.

Como señaló Raquel Asún, la conmemoración de Góngora en 1927 no impidió que los escritores de esa generación se hubiesen interesado por otros clásicos, en su afán por «recuperar y vitalizar ese pasado cultural que se siente como una herencia fecundante» ${ }^{46}$. Se reivindicó a Quevedo juntamente con Garcilaso, fray Luis de León y Lope de Vega pues, como afirmó Calvo Carilla, «los jóvenes del 27 (Aleixandre, Cernuda, Lorca, Alberti) iban a conectar muy pronto con el Quevedo del sentimiento ${ }^{47}$. En el paralelo centenario de Goya de 1927 también se destacó una especie de Quevedo surrealista, en oposición al Góngora de la deshumanización y el arte puro ${ }^{48}$. Poco después, en las revistas Cruz y Raya (1933-1936) y El Gallo Crisis (1934-1935) se resaltaron otras facetas: el Quevedo meditativo, el opuesto a la decadencia del país ${ }^{49}$, o, en palabras de Ramón Sijé, el hombre «en zapatillas, en carne viva, en humor vivo ${ }^{50}$. Al buscar nuevos caminos líricos, los poetas de la mencionada generación contribuyeron a afianzar la imagen de un Quevedo estimable no sólo por su estilo, sino también por sus ideas y actitudes. Así pudo haberle sucedido a Valle-Inclán: cuando se proclamó «continuador de

43. Quevedo, Homme du diable, homme de Dieu, Paris, Honoré Champion, 1929, pp. 5, 12 y 7 respectivamente. Las reservas con que Américo Castro reseñó este libro (Revista de Filología Española, 21 [1934], pp. 171-78), atañen a otros contenidos.

44. Historia de la lengua y literatura castellana, edición facsímil, Madrid, Gredos, 1972, IV, p. 163.

45. Conferencias sobre Quevedo, Madrid: Calleja, 1945, p. 177.

46. «1927 y la literatura clásica: presencia de fray Luis de León», Studia in honorem profesor Martín de Riquer, 1986, I, p. 202.

47. Quevedo y la generación del 27, Valencia, Pre-Textos, 1992, p. 64.

48. Cfr. Agustín Sánchez Vidal, Buñuel, Lorca, Dali: el enigma sin fin, Barcelona: Planeta, 1988 , p. 143.

49. Quevedo y la generación del 27, p. 82.

50. El Gallo Crisis, 3-4, 1934, pp. 5-6. 
una tradición de juicio y protesta éticos» ${ }^{51}$, aseguró encontrar en el ser de España «una fuerza ética» de la cual Séneca y Quevedo eran un ejemplo ${ }^{52}$.

Mención aparte merece la colección "Quevedo" que, dentro de la editorial Mundo Latino, puso en marcha Eduardo Barriobero y Herrán, complejo anarquista y federalista que hizo compatible su radicalismo político con el deseo de recuperar la tradición literaria española. De manera más concreta debe destacarse su antología Doctrinal de Quevedo, de los reyes, de los ministros ${ }^{53}$, selección de pensamientos susceptibles de ser aplicados al momento de aparición del libro, en el curso del cual Barriobero ensalza especialmente Política de Dios y Marco Bruto, al tiempo que pone a Quevedo, junto con Cervantes, en el punto más alto de la cultura española. Tanto en la colección «Quevedo» como en el Doctrinal resulta visible el interés de un hombre de izquierdas por insuflar nuevas ideas a la clase media ilustrada, siendo Quevedo, junto con Cervantes, Mariana y Rabelais, sus principales apoyos dentro de la literatura del pasado.

Posiblemente bajo el duradero influjo de Fernández-Guerra, Juan Valera y Mérimée, casi todos los ensayos sobre Quevedo de la primera mitad del siglo XX destacaron su lucha por la justicia, la ambición intelectual y el talento satírico, a la vez que lamentaban la escasa originalidad conceptual de sus tratados, la ausencia de un plan riguroso y la artificiosidad estilística. Emilio Carilla resumió ese sentir a propósito de las obras políticas: si bien «desparejas, desordenadas, de escaso valor como tratados [...] las sentimos más cerca, sobre todo cuando defiende en ellas la libertad, cuando fustiga la tiranía, porque sabemos que hubo identidad entre el pensar y el hacer del autor ${ }^{54}$. Redundó en parecidos juicios la peculiar biografía que Gómez de la Serna dedicó a Quevedo: «Hondamente creyente, mezcla la política de Dios a la política de los reyes, y entonces se produce una excesiva homilía contra los poderosos» ${ }^{55}$.

Gregorio Marañón no participó de la favorable acogida que tuvo Quevedo en las primeras décadas del siglo XX. En la biografía que publicó sobre Olivares en 1939 dibujó una relación con el escritor opuesta a la que había

51. Véase Mario Hernández, "Valle Inclán, de Darío a Quevedo», en Quevedo a nueva luz: escritura y politica, ed. de Lía Schwartz y Antonio Carreira, Málaga, Universidad, 1997, p. 340.

52. Cito por Dru Dougherty, Un Valle-Inclán olvidado, Madrid, Fundamentos, 1983, p. 199.

53. Madrid, Galo Sáez, 1930.

54. Quevedo (entre dos centenarios), Tucumán, Universidad Nacional de Tucumán, 1949, p. 153.

55. Quevedo, Madrid, Espasa Calpe, 1962, p. 111. 
dominado en los dramaturgos románticos. Al mismo tiempo, marcó más claramente que Menéndez Pelayo, y con otra intención, los perfiles de una personalidad borrascosa:

Y no bueno, hay que decirlo, no muy bueno fue don Francisco de Quevedo. Sus pasiones eran terribles. Él mismo se confesaba envidioso. Pasaba con ligereza lamentable de la adulación a los personajes poderosos a una mortal enemistad, según cual fuese la cuantía de lo que le daban. Y aunque todo se borra ante su genio, el historiador tiene que recordarlo cuando se trata de juzgar, en su relación con él, a los demás hombres de su época ${ }^{56}$.

Oponiéndose a las versiones usuales sobre la prisión de Quevedo en 1639, Marañón se inclinó por aceptar el comentario de Pellicer acerca de una imprecisa connivencia con el gobierno francés de Richelieu. Así, del romántico Quevedo que sacrifica su vida por la libertad se pasó al conspirador y espía de franceses, tesis grata, con otros matices, a investigadores posteriores. Empezó a delinearse ahí la estampa de un escritor aliado con aristócratas y terratenientes frente al espíritu reformista y modernizador del CondeDuque.

El interés de Jorge Luis Borges y Raimundo Lida por Quevedo se prolongó durante muchos años, de modo que no es fácil situarlos en un punto fijo dentro de la cronología que vengo recorriendo. La distancia temporal entre sus publicaciones tempranas y las tardías explica también algunas interesantes variaciones en sus juicios. Por ello, y por su condición de argentinos internacionales provistos de una peculiar perspectiva cultural, procede hacer un pequeño aparte con uno y otro.

A Borges le corresponde el mérito de haber puesto un nuevo énfasis en la originalidad estilística de Quevedo. Sus breves ensayos, prólogos y entrevistas, siempre adornados de agudeza, ocupan un lugar reseñable en la bibliografía quevediana. En «Menoscabo y grandeza de Quevedo» (1923) llevó a cabo un sumarísimo recorrido por varios de sus libros, que encontró "cotidianos en el plan, pero sobresalientes en los verbalismos de hechura ${ }^{57}$. Instalado en el amplio espacio de las lenguas y literaturas que frecuentó, no se interesó por la dialéctica de los géneros del Siglo de Oro, y probablemente le ocurrió

56. El Conde-Duque de Olivares, Madrid, Espasa-Calpe, $1975^{14}$, pp. 102-03. Compárese con este juico de John Elliott: «No está del todo descartado que el retorcido, corrosivo y amargado Quevedo viera en la Francia de Luis XIII un posible instrumento para derrocar a un ministro tiránico que estaba conduciendo al país hacia la destrucción»; El Conde-Duque de Olivares, Barcelona, Crítica, 1990, p. 544.

57. Inquisiciones, Barcelona, Seix Barral, 1994, p. 44. 
así con Marco Bruto, Política de Dios, La Fortuna con seso, Providencia de Dios o Discurso de todos los diablos, que interpretó por medio de originales y ahistóricas imágenes. No se le ocultó el ímpetu satírico de muchas páginas de Quevedo y la diversidad de asuntos tratados, pero no se centró en los aspectos temáticos de su obra porque, como señaló en otro ensayo de 1952, consideró que su grandeza fue verbal, no de temas o ideas ${ }^{58}$. En cuanto a su estilo, le entusiasmó al principio y le cansó años después: «Sí, yo creo que tenía una admiración excesiva por Quevedo. Y los que me curaron de esa admiración excesiva fueron dos: uno, Adolfo Bioy Casares, y el otro, el mismo Quevedo, a quien yo he tratado de releer, y que me parece ahora un literato demasiado consciente de lo que hace [...] Actualmente, mi admiración por Quevedo es muy limitada " ${ }^{59}$.

En cierto modo, Raimundo Lida desarrolló las incitaciones de los ensayos borgianos, partiendo de una visión análoga de Quevedo ${ }^{60}$. En un libro póstumo de 1981 se reunieron, actualizados, sus artículos publicados durante los años 50 y 60, que versan sobre las cartas, Introducción a la vida devota, Política de Dios, el Buscón, España defendida, los Sueños y La Fortuna con seso. Es tarea compleja sintetizar las páginas de tan original y perspicaz crítico, porque su libre discurrir por multitud de aspectos se fragmenta en la misma medida en que ilumina cada uno de ellos. Resulta sintomática la visión de Quevedo que ofrece la contracubierta del libro: «una obra en prosa en que tan a menudo las partes son mayores que el todo, en que los detalles son más sutiles, más hábiles, más graciosos, a menudo más grandiosos o estremecedores que el todo». Tal descripción podría ajustarse más al modo de trabajar de Lida que al del poeta, pues aquél confiesa en el prólogo que ofrece «esbozos, invitación a estudios más detenidos». En lo que atañe a la interpretación ideológica de Quevedo no es fácil ofrecer una visión unificadora de los trabajos reunidos en 1981, porque cuando uno espera encontrar una recapitulación, el ensayista se evade con una suerte de pirueta borgiana o con una conceptuosa referencia a algún lugar paralelo. Hay comentarios admirables sobre Politica de Dios, Marco Bruto o Providencia de Dios, pero no una interpretación abarcadora de cada una de estas obras, o un cabal emplazamiento dentro de la pertinente tradición doctrinal y literaria.

58. Otras inquisiciones, Buenos Aires, Sur, 1952, p. 68.

59. Cito en este caso por Fernando Sorrentino, Siete conversaciones con Jorge Luis Borges, Buenos Aires, Editorial El Ateneo, 2001, pp. 194-95.

60. En Borges, sus días y su tiempos (Buenos Aires-Madrid-México-Santiago de Chile, Javier Vergara, 1984, pp. 285-302) aparece recogido un interesante diálogo literario entre Borges y Lida, con algunos comentarios sobre Quevedo. La conversación con Lida empieza en la página 291. 


\section{LA CONSTRUCCIÓN CRÍTICA DE UN QUEVEDO REACCIONARIO}

Con todo, se diría que Lida no quiso dejar escapar la ocasión de poner a Quevedo en las filas conservadoras. Con erudición y sutileza hizo preceder su análisis de Política de Dios con referencias a las guerras carlistas, a un catecismo bélico de la Guerra de Independencia y a Marinetti; y al ocuparse del episodio de la Isla de los Monopantos volvió sobre el estudio de Van Praag de 1949 para mostrar su concordancia con cierta literatura antijudía del siglo XIX alemán ${ }^{61}$. Insinuaciones contenidas, pero inequívocas. También son llamativos sus titubeos acerca de la frase «Toda la sangre, hidalguillo, es colorada», con la que un diablo del Sueño del infierno se burla del hidalgo necio ${ }^{62}$. Lida evocó «los pruritos genealógicos que están en la base de tanta afirmación y tanta negación del señor de la Torre de Juan Abad», como si temiese ver en la pluma de Quevedo una frase «digna de 1789 o de $1917{ }^{63}$. Sorprende que hubiese planteado la cuestión en tales términos, cuando hubiera sido muy sencillo soslayarla recordando lo obvio: que Quevedo prefirió la virtud a la honra siguiendo una corriente de pensamiento que arranca de Aristóteles y Juvenal, cuya sátira VI fue recordada a menudo ${ }^{64}$.

En una monografía de 1970, Doris L. Baum interpretó la vida y obra de Quevedo a la luz de un concepto muy próximo a lo que Menéndez Pidal había denominado tradicionalidad, es decir, conservación del pasado, actitud compatible con la novedad y el progreso:

Like a solitary voice in a desert of complacency, Quevedo's militant traditionalism represents an unparalleled effort to sustain the essential ideals of Hispanic culture amid the apathy which invaded national life at every level during the early seventeenth century. Other writers joined him in combatting one or another of the aspects of literary, social or political deterioration, but none of his colleagues took the same comprehensive stand against all forms of national decay as did Quevedo ${ }^{65}$.

61. Cfr. Prosas de Quevedo, Barcelona, Crítica, 1980, pp. 125-29 y pp. 150-55, respectivamente.

62. "Acabaos de desengañar que el que deciende del Cid, de Bernardo y de Godofredo y no es como ellos, sino vicioso como vos, ese tal más destruye el linaje que lo hereda. Toda la sangre, hidalguillo, es colorada, y parecedlo en las costumbres y entonces creeré que decendéis del docto cuando lo fuéredes o procuráredes serlo, y si no, vuestra nobleza será mentira breve en cuanto durare la vida», edición de Ignacio Arellano, en Obras completas de Quevedo, Madrid, Castalia, I, 2003, pp. 298-99.

63. Prosas de Quevedo, p. 11.

64. Más datos en torno a esta cuestión en Alfonso Rey, «Concepto de nobleza y visión de la guerra en la obra de Quevedo", en Rostros y máscaras: personajes y temas de Quevedo, edición de Ignacio Arellano y Jean Canavaggio, Pamplona, Eunsa, 1999, pp. 133-60.

65. Traditionalism in the Works of Francisco de Quevedo y Villegas, Chapel Hill, The University of North Carolina Press, 1970, p. 14. 
Baum concluyó sugiriendo que el legado quevediano perdura en escritores como Menéndez Pelayo, Ganivet o Ramiro de Maeztu. Su libro presenta indudables puntos de contacto con los estudios del siglo XIX y XX citados anteriormente, que trataron de comprender el conjunto de la vida y obra de Quevedo a la vez que alabaron su lucha contra la decadencia de Espańa. Pero tal vez Baum, sin pretenderlo, contribuyó a fomentar una lectura de Quevedo donde algunos llamaron reaccionario lo que ella denominó traditionalist.

\section{ENTRE I967 Y I977}

«No es la conciencia del hombre la que determina su ser sino, por el contrario, el ser social es lo que determina su conciencia». Estas palabras de Marx en el prólogo a Contribución a la crítica de la economía politica podrían servir de lema para caracterizar la nueva etapa en los análisis ideológicos de Quevedo.

En el curso de un libro sobre Góngora, Robert Jammes dijo que los Sueños «expriment une hostilité sans réserve à l'égard de toute activité artisanale ou commerciale» así como "le point de vue ultraréactionnaire d'une classe jalousement attachée à ses privilèges et particulièrement méfiante à l'égard de tout ce qui représente le germe d'une classe rivale susceptible de la supplanten;; que La Hora de todos, también contraria al comercio, está impregnada de "xénophobie» y "nationalisme et catholicisme exacerbés»; que en los retratos femeninos, "sa misogynie est totale, absolue, et elle se fonde sur l'ascétisme chrétien le plus strict). De modo que «si l'on veut réduire ces deux termes (nationalisme et catholicisme) à un seul, c'est finalement au catholicisme quil faut aboutir: Politica de Dios y gobierno de Cristo, tel est bien le programme que l'on retrouve au fond de toute cuvre polémique et non polémique de Quevedo»" Triple condena de éste, por noble, por católico y por español.

Esta nueva visión de la ideología quevediana se consolidó en torno al Buscón, contrapunto aristocrático del Guzmán de Alfarache según Cécile y Michel Cavillac. En el sentir de estos críticos, Quevedo, «gardien zélé des traditionnelles vertus seigneuriales», escribió su relato picaresco para contrarrestar la problemática burguesa del de Alemán, de modo que el Buscón podría considerarse un libro proaristocrático ${ }^{67}$, a pesar de que también ofrece

66. Études sur l'ceuvre poétique de don Luis de Góngora y Argote, Université de Bordeaux, Institut d'Études Ibériques et Ibéro-Américaines, 1967, pp. 55, 59, 61-62 y 59 para las cuatro citas.

67. «À propos du Buscón et de Guzmán de Alfarache», Bulletin Hispanique, 75, 1973, p. 131. 


\section{LA CONSTRUCCIÓN CRÍTICA DE UN QUEVEDO REACCIONARIO}

la «expression non conformiste [...] de l'orthodoxie nobiliaire» por medio de un conservadurismo "corrosif». La misma premisa sustenta la primera de las monografías que Edmond Cros dedicó al Buscón: «il est significatif, sur ce point, de voir un aristocrate comme Quevedo exprimer ce qu'il perçoit comme la menace d'une montée subversive sous la forme d'une mascarade généralisée»" ${ }^{68}$. Más contundente fue Maurice Molho: "Quevedo puso toda su energía en organizar y defender, desde su clase, los intereses de la clase. Puede decirse, pues, recurriendo a la terminología de Gramsci, que se empeñó en afirmarse como «intelectual orgánico» de la aristocracia espańola». Tras esa valoración, caracterizó el Buscón como un libro concebido "para dar al grupo hegemónico, y en especial a la casta dominante, la conciencia de su dominación ${ }^{69}$.

Quizás la publicación en 1964 del libro de Lucien Goldmann, Pour une sociologie du roman, estimuló el interés por las relaciones entre la obra literaria y la estructura social, aunque debe decirse que, con la salvedad de un estructuralista como Edmond Cros, en bastantes estudiosos de Quevedo ha prevalecido un enfoque inspirado en Gramsci y su visión de los intelectuales como «empleados del grupo dominante para el ejercicio de las funciones subalternas de la hegemonía social y de gobierno político» ${ }^{70}$. En concordancia con tal premisa, no pocas interpretaciones de Quevedo resaltaron su condición de señor de la Torre de Juan Abad o sus relaciones con los nobles ${ }^{71}$, centrándose en su biografía más que en un cotejo entre la estructura literaria y la económica ${ }^{72}$. Inevitablemente, el contradictorio escritor estoico y cristiano dio paso a otro más onedimensional, interesado en

68. L'aristocrate et le carnaval des gueux, Montpellier, Université Paul Valéry, 1975, p. 9.

69. Semántica y poética (Góngora, Quevedo), Barcelona, Crítica, 1977, pp. 99 y 102, respectivamente.

70. Cito por Cultura y literatura, traducción de Jordi Solé Tura, Barcelona, Península, 1977, p. 35.

71. En algunos casos se habla de la relación de Quevedo y la nobleza de un modo similar a lo que dijo Gramsci de Croce: «se siente fuertemente ligado a Aristóteles y Platón pero no oculta sus lazos con los senadores Agnelli y Benni; en esto, precisamente, se debe buscar la característica más relevante de la filosofía de Croce». (Cultura y literatura, p. 30). Sin hacer valoraciones de esa naturaleza, Antonio López Ruiz acompañó con diversos datos un interesante apunte sobre las relaciones entre Quevedo y los nobles andaluces. Véase Quevedo. Andalucía y otras buisquedas, Almería, Zéjel, 1991, pp. 249-98.

72. Pese a que Goldmann había indicado que «las tentativas de poner en relación las obras culturales con los grupos sociales como sujetos creadores se revelan [...] mucho más operatorias que todos los intentos de considerar el individuo como el verdadero sujeto de la creación». Para una sociología de la novela, Madrid, Ciencia Nueva, 1967, p. 225. 
la defensa del «complejo monárquico señorial» ${ }^{73}$, de quien también se valoró negativamente su condición de católico y español.

En 1972 se publicó Teatro y literatura en la sociedad barroca, en cuyas páginas José Antonio Maravall expuso su interpretación del teatro del XVII como una extensa forma de propaganda destinada a difundir la ideología e intereses de los grupos dominantes, tesis reiterada en otro libro de 1975, La cultura del Barroco, donde reafirma que la creación artística de este período, hábilmente dirigida, tiene un carácter conservador, con elementos de refeudalización ${ }^{74}$, reflejo de una nobleza que, sintiendo amenazados sus privilegios, dificulta el ingreso en sus filas. La visión de unos dramaturgos enmascarando la realidad para crear mitos e ilusiones favorables a los grupos sociales más conservadores resultaba demasiado atractiva para no aplicarla a Quevedo. Con este trasfondo conceptual (recuérdese también a J. P. Sartre ${ }^{75}$ y su diatriba contra la irresponsabilidad del escritor burgués, o la descripción que hizo Theodor W. Adorno ${ }^{76}$ del escritor como «lugarteniente»), en la cercanía al exilio republicano de Toulouse, Burdeos, Montpellier y París, con el franquismo en su ocaso, comenzó a fortalecerse la imagen de un Quevedo conservador. Tal semblanza, que tuvo en el Buscón su principal punto de referencia, se extendió luego a otros ámbitos académicos y se aplicó a más obras del escritor ${ }^{77}$.

73. Cumple señalar la postura más equilibrada de Carlos Blanco Aguinaga, Julio Rodríguez Puértolas e Iris M. Zavala en su Historia social de la literatura española (Madrid, Castalia, 1978, I, 327-28): «Feroz y machaconamente antisemita, grotesca y vulgarmente antifeminista, patriotero y casticista hasta extremos hoy, desde luego, intolerables, es también un extraordinario crítico de la sociedad decadente, fantasiosa y vulgar de su tiempo; terrible desmitificador, noble pensador político obsesionado por la dignidad humana, sabio y erudito...".

74. La cultura del Barroco, Barcelona, Ariel, 1975, pp. 301-02.

75. Me refiero a Qu'est-ce que la littérature?, sin olvidar, de 1965, Que peut la littérature?, con intervenciones de Simone de Beauvoir, Yves Berger, Jean-Pierre Faye, Jean Ricardou, Sartre y Jorge Semprún, Paris, l'Inédit 10-18, 1965.

76. Véase T. W. Adorno Crítica cultural y sociedad, traducción de M. Sacristán, Barcelona, Ariel, 1969, pp. 185-201.

77. Quizás convenga recordar que en los estudios de Nicolás Díaz de Benjumea, posteriores a 1859, se contrapone «al caballero de izquierdas cervantino con una contrahechura mojigata y reaccionaria», representada, fundamentalmente, por Lope de Vega y López de Úbeda. En El pensamiento de Cervantes (1925), Castro acentuó los rasgos laicos y liberales del autor del Quijote para situarlo en una órbita moderna y europea aunque en España en su historia (1948), dando un giro a sus ideas, propuso una identidad del pueblo espańol basada en la convivencia de tres religiones. Tal vez cierta idealización literaria y conceptual de los conversos propició una mayor hostilidad hacia el antijudaísmo quevediano. 


\section{LA CONSTRUCCIÓN CRÍTICA DE UN QUEVEDO REACCIONARIO}

La vocación científica del materialismo histórico suele ir unida a una suerte de conciencia de superioridad que permite alabar los aspectos del pasado semejantes a los de hoy y desdeñar los que no anticiparon logros que vinieron más tarde. Tal vez ese hábito pervive en aquellos lectores de Quevedo que contemplan su vida y obra con la seguridad de saber qué era lo correcto hace cuatro siglos. Si el duque de Maura ${ }^{78}$ elogió a Quevedo por poseer «cuatro sólidas vallas infranqueables: la religión, el patriotismo, el monarquismo y la hombría de bien", la nueva valoración marchó en dirección opuesta. Cabe hablar de una nueva orientación en los estudios de Quevedo cuando, en un período temporal bien delimitado, varios especialistas coinciden en sus análisis, sus valoraciones e, incluso, las expresiones utilizadas, entre las que no falta el adjetivo reaccionario o un sinónimo. Algunos ejemplos:

un problema [la existencia de ricos y pobres] tan a propósito para referirse objetivamente a las realidades sociales de su tiempo, por vía de moralización se transforma en un narcótico de la lucidez de los indigentes [...] un medio de autojustificación para las clases más o menos adineradas, público lector potencial a quien se dirige [Quevedo, a quien] se le trasluce un deje de moral insolidaria que casa con el hartazgo de tópicos librescos que receta a los pobres, y con el que repinta, con barniz mixtificante, la situación privilegiada de los acaudalados ${ }^{79}$.

Quevedo representó su papel literario a las mil maravillas, haciendo poema de toda medida social vivida o testificada, ya personalmente, ya aprendida en los libros. Su ideología, a pesar de su componente reformista, se define primordialmente por su compromiso en la apología patriótica del sistema establecido, propagando el modo de pensar y los intereses del complejo monárquico-seńorial y del absolutismo cristiano. Se trata de un conservadurismo ideológico acompañado, como momento más característico de su reluctancia al cambio, de un permanente antisemitismo, con las correspondientes implicaciones en política, religión y sociedad ${ }^{80}$.

El Buscón es una máquina de guerra de la aristocracia contra los que quieren invadirla. La historia de Pablos, que quería entretener a los cortesanos, es también una llamada a la autodefensa de los

78. Conferencias sobre Quevedo, Madrid, Calleja, 1945, p. 183.

79. José María Balcells, Quevedo en "La cuna y la sepultura», Madrid, SGEL, 1981, pp. 158-59.

80. Juventino Caminero, Victima o verdugo: conservadurismo y antisemitismo en el pensamiento social de Quevedo, Universidad de Deusto, Reichenberger, 1984, p. 101. 
mismos para que se protejan contra el asalto de las clases bajas en nombre de un concepto conservador de la sociedad ${ }^{81}$.

Pero no puedo dejar de pensar que si Quevedo hubiese tenido que vivir en nuestra época, habría sido franquista o nacionalista y sin lugar a equívoco, acá en Buenos Aires se habría afiliado al movimiento peronista ${ }^{82}$.

[Quevedo] es el heredero de una poderosa familia de "funcionarios» de Palacio, con formación humanística, quien empieza a destilar su venenosa sabiduría a través de esa mirada despectiva hacia el mundo burgués, casi siempre aplebeyado en sus páginas [...] Sus apetencias sociales, claro está, apuntan hacia arriba, círculos cerrados y conservadores, para lo cual marca rotundamente su distancia con el patriciado urbano, las clases mercantiles, los oficios, la plebe ${ }^{83}$.

Esta actitud, a la vez providencialista y carnavalesca, es la clave del carácter jánico de Quevedo: por el lado del concepto filosófico un personaje nada recomendable, reaccionario, xenófobo, antisemita, misógino ${ }^{84}$.

El "uso" de la epístola horaciana diferenciará al Garcilaso hastiado y burlón de su composición dirigida a Boscán, del Francisco de Aldana que ilumina de neoplatonismo su carta a Arias Montano [...] o del reflexivo y preciso senequismo de la Epistola moral a Fabio, o del hervor político - ¡tan reaccionario!- en la Satírica y censoria enderezada por Quevedo al conde-duque de Olivares ${ }^{85}$.

No hubo manera de paliar lo que se puede considerar una ¿disculpable?, ¿trágica?, limitación. El empecinamiento nacionalista y tridentino resultaron infranqueables y una y otra vez Quevedo se muestra insensible al aire europeo más renovador y abierto al futuro [...] Las persecuciones, procesos, disfavores, destierros y

81. Jacques Joset, ed., Alonso de Castillo Solórzano, Aventuras del bachiller Trapaza, Madrid, Cátedra, 1986, p. 40.

82. Cito por el libro de Waldermar Verdugo-Fuentes, En voz de Borges, Tepepan (México), Editorial Offset, 1986, p. 174.

83. Pablo Jauralde, Francisco de Quevedo (1580-1645), p. 132.

84. Antonio Carreira, «El conceptismo en las jácaras de Quevedo: "Estábase el padre Esquerra"”, La Perinola, 4, 2000, p. 92.

85. José Carlos Mainer, Historia, literatura, sociedad (y una coda española), Madrid, Biblioteca Nueva, 2000, p. 97. 


\section{LA CONSTRUCCIÓN CRÍTICA DE UN QUEVEDO REACCIONARIO}

encarcelamientos no contribuyeron a que se replanteara lo más mínimo su modo de pensar a contracorriente ${ }^{86}$.

Quevedo quiere que una vez que su texto haya alcanzado a los grupos dominantes, llegue al lector para conformar una opinión pública que favorezca sus proyectos [...] La nobleza debe tomar nota de lo expuesto por Quevedo. Si no le presta atención y no actúa, la caída de España será inevitable [...] Una población uniformada en una historia común, una lengua, una religión, unas costumbres podía seguir sin problemas a una corona poderosa; a la vez que el Rey y sus ministros podían utilizar este sentimiento nacional para conseguir sus propósitos políticos ${ }^{87}$.

Por lo que respecta a Quevedo, sabemos que se pasó toda la vida merodeando las cortes de poderosos nobles [...] fue un agente del duque de Osuna en Nápoles cuya misión consistía en comprar voluntades mediante cuantiosas sumas de dinero [...] Y desde esta situación es normal que lo defina como "poderoso caballero", al que no se denigra precisamente. Su sátira, si es que la hay, es más bien un ejercicio de cinismo, pues él es ejecutor de los desperfectos que denuncia $^{88}$.

El nuevo enfoque es estimulante en la medida en que llama la atención sobre datos anteriormente desatendidos y propone una visión menos complaciente del Quevedo «eminente español y católico» grato a algunos panegiristas. No obstante, explicarlo a la luz de la lucha de clases y estamentos conduce a conclusiones previsibles y limitadas: previsibles, porque, cuando las conclusiones son correctas, resultan aplicables a escritores de muy diferente perfil; limitadas, porque sólo aclaran una pequeńa parcela de la obra quevediana. Por lo demás, es notable el apasionamiento de ciertos juicios, de los que se podría decir, con terminología de Jakobson, que en ellos la función emotiva prevalece acusadamente sobre la referencial. El DRAE llama reaccionario a quien "pretende restablecer lo abolido», pero no es fácil sostener que Quevedo persiguió tal fin de manera concordante en los campos de la moral, la teología, la economía, la política, la vida social y la literatura ${ }^{89}$.

86. Antonio Martínez Sarrión, Francisco de Quevedo: Bilis negra, con grabados de Julio Zachrisson, Madrid, Gredos, 2002, pp. 7-8.

87. Francisco Vivar, Quevedo y su España imaginada, Madrid,Visor, 2002, pp. 50 y 52.

88. Juan Victorio, "Poderoso caballero es don Dinero": Juan Ruiz y Quevedo a la luz de un tema convergente», La Perinola 12, 2008, p. 254.

89. Tal matiz no pasó inadvertido a J. Ignacio Díez Fernández: «no estoy sugiriendo que Quevedo sea un ilustrado, condición a todas luces imposible en la España de 1625, 
Probablemente el mencionado vocablo proviene de la metodología marxista. Como afirmó Lukács, «mientras en el seno de cada nación la lucha de clases constituye el motor de la evolución, toda apelación teorética directa a la humanidad, saltando por encima de aquellas objetivas mediaciones, tiene que violentar los verdaderos contenidos y formas de la realidad, con un resultado falso y a menudo reaccionario» ${ }^{90}$. Presumiblemente el filósofo húngaro juzgaría en tales términos la obra de Quevedo.

Tal imagen aparece reforzada por la creencia, explícita unas veces, latente otras, de que éste fue también un deficiente humanista, un pensador limitado, sólo capaz de enaltecer estilísticamente una visión estrecha de la realidad. De ser así, uno esperaría que la atención de los críticos se encaminara hacia el estudio del estilo, contrapunto positivo de unas ideas pobres; paradójicamente, no suelen emprenderlo quienes más insisten en su banalidad intelectual, que tanto parece atraerles. Leyendo algunos estudios se diría que fue materia progresista todo aquello que recibió alguna crítica de Quevedo: el patronato de santa Teresa, los genoveses, los marranos portugueses, los taberneros, Maquiavelo, los letrados, Richelieu, los ejércitos protestantes, los rebeldes catalanes, el navegante codicioso de Horacio, los gastos suntuarios, las corridas de toros... Incluso meras cuestiones de técnica militar, como la presencia del rey al frente del ejército, o de actitud ante el paisaje han sido interpretadas como indicio de una ideología retrógrada ${ }^{91}$.

sino que el memorial que es la Epistola satírica y censoria, en la que dominan los contenidos reaccionarios, tiene también tintes modernos, probablemente por la necesidad de una crítica intensa, si no sistemática, de las "costumbres presentes de los castellanos" y, al mismo tiempo, por el carácter pragmático y utilitario de Quevedo». Véase "La Epistola satírica y censoria: un memorial reaccionario... y moderno", La Perinola 12 (2008), p. 62.

90. Prolegómenos a una estética marxista, traducción de Manuel Sacristán, México, Grijalbo, 1965, p. 303.

91. Algunas muestras: «Es lástima no poder contemplar los cuadros que [Quevedo] pintó en cierta época de su vida, porque a lo mejor le sucedía lo que al general Franco, que cuando estaba en su finca de Navalcarnero, en plena meseta castellana, sacaba el caballete, ponía sobre él un lienzo, y pintaba paisajes marinos» (Antonio Carreira, «El conceptismo en las jácaras de Quevedo», p. 92). «La imagen más genuina de Quevedo recoge, junto a las intransigencias del reaccionario, la ceguera del cortesano para el paisaje y el campo, la del súbdito fidelísimo a su rey, la del español idealista y jactancioso que desprecia las "cuestiones materiales"» (Pablo Jauralde, edición de Obras festivas, Madrid, Castalia, 1981, p. 13). También podría haber proyectado su misoginia a la hora de describir Venecia: según Encarnación Juárez, en Mundo caduco y desvarios de la edad "Quevedo reduce metafóricamente los dos enclaves geográficos [las montańas de Croacia y Venecia] a dos núcleos semánticos opuestos: la mujer corrupta, sexual e inmoral que vende su cuerpo y la belicosa madre con cuerpo inaccesible, protectora pero infértil. De la misma forma que se oponen los enclaves geográficos se contrastan los grupos sociales. Los venecianos se construyen como los corruptos habitantes civilizados de la 
El descubrimiento en 1991 de Execración por la fe católica contra la blasfema obstinación de los judios que hablan portugués y en Madrid fijaron los carteles sacrílegos y heréticos (tal es el título de los dos manuscritos conocidos, no, con extraña abreviación, Execración contra los judios) reafirmó la imagen del peor Quevedo'.

En 1982 Maravall, sin pretender «negar en modo alguno las interpretaciones al uso que nos presentan a un Quevedo colaborador endurecido de la política de apuntalamiento de la sociedad jerárquica», formuló la cauta hipótesis de que el autor del Buscón se movía en la franja «estrecha, desde luego, pero patente a la observación, en la cual una ideología orientada a la estabilidad puede contar y cuenta con la transformación»" ${ }^{33}$. A tal fin propuso una revisión del pensamiento quevediano, advirtiendo implícitamente a los historiadores de la literatura de la imprecisión con que utilizaban algunos conceptos historiográficos al referirse a la monarquía absoluta, la guerra, el maquiavelismo, el tomismo, la riqueza o la religión ${ }^{94}$. Tal estudio, que venía a paliar las aplicaciones más dogmáticas de sus propias tesis sobre el Barroco, podrá proporcionar algunas pautas para una mejor historización de Quevedo ${ }^{95}$. Pues lo que Maravall terminó denominando «interpretaciones

edad de hierro exentos de virtudes varoniles y los uscoques como los naturalmente honrados y valientes de la Edad de Oro. En la fábrica de Quevedo los tropos locales se revisten de un significado político y moral conectado con las características de los pueblos que habitan esos lugares». Cfr. «Quevedo, Contreras, Duque de Estrada y sus conceptos del Mediterráneo», La Perinola, 10 (2006), pp. 371-72.

92. Según James Iffland, Quevedo se opuso a «un naciente sistema económico y sociopolítico que iba a condenar a gente [como él] al basurero de la Historia», precisando que la arenga anticapitalista es consecuencia de una previa "pulsión anímica antijudía». Véase, "Qué hacer con los textos tóxicos. El caso de Execración contra los judios de Francisco de Quevedo", La Perinola, 2010, pp. 177-78.

93. "Sobre el pensamiento social y político de Quevedo (una revisión)", Homenaje a Quevedo, ed. Víctor G. de la Concha, Salamanca, Universidad, 1982, pp. 72 y 73 para ambas citas.

94. Se apoyó Maravall, preferentemente, en La hora de todos, aunque también tomó en consideración, de forma esporádica, obras como Discurso de todos los diablos, Marco Bruto, Politica de Dios, España defendida, Genealogía de los modorros, El chitón de las tarabillas, los Sueños, el Buscón.

95. Otro fue el parecer de Santiago Fernández Mosquera: «Por lo tanto, cuando Maravall cree que Quevedo escribe apoyando al régimen y a fuerza de discrepar lo subvierte, lo que hace realmente Quevedo es escribir en contra del régimen que ya era distinto y comenzaba a ser moderno [...] Y con Quevedo estaban aquellos que deseaban volver a una estructura aristocrática más tradicional, como Osuna o, en un primer momento, Medinaceli, sus mecenas, amigos y la oposición a Olivares [...] Por lo dicho, la ideología de Quevedo que traza Maravall debe considerarse con las prevenciones seńaladas; las novedades que él indica en su pensamiento no son tanto ideológicas como literarias; sus pensamientos claramente 
al uso» ha tenido como principal consecuencia la consolidación de usos terminológicos inexactos (mercantilismo, providencialismo, anticapitalismo, burguesía, trabajo) que, con su simple mención, orientan ideológicamente hechos que admiten -o exigen- otro tipo de explicación, de modo que, afianzando la visión del Quevedo reaccionario, terminan por hacerla indiscutible. Algo similar ha ocurrido con un episodio de su vida, la relación con Olivares, insuficientemente estudiada pero de la cual se suelen extraer conclusiones ideológicas aún no confirmadas por las investigaciones.

\section{MerCantilismo}

Antimercantilista es un vocablo frecuentemente aplicado a Quevedo con el no documentado significado de "contrario al trato mercantil», «hostil a la burguesía", tal vez descuidando el dato de que buena parte del comercio en la Espańa del XVII estaba en manos de la nobleza. El DRAE ofrece dos acepciones para la voz «mercantilismo». Según la primera, quiere decir «espíritu mercantil aplicado a cosas que no deben ser objeto de comercio». Consiguientemente Quevedo es antimercantilista cuando satiriza la venalidad en las oraciones, en el desempeño de los cargos, en las relaciones íntimas y así sucesivamente. No interesa detenerse en algo tan común a los moralistas de todas las épocas. En la segunda acepción del DRAE, el mercantilismo es el «sistema económico que atiende al comercio de exportación y considera la posesión de metales preciosos como signo característico de riqueza». Eli F. Heckscher lo describió como una doctrina, propia de los siglos XV a XVIII, que, aspirando a poner la economía al servicio del estado, propugnó el proteccionismo, la acumulación de metales preciosos y la consecución de un excedente de las exportaciones sobre las importaciones ${ }^{96}$. Quevedo ofrece rasgos mercantilistas ${ }^{97}$, como corresponde a un nacionalista (otro

reaccionarios pueden estar dictados, o al menos influidos, por circunstancias concretas»; véase "Ideología y literatura: perturbaciones literarias en la exégesis ideológica de Quevedo», $L a$ Perinola, 1 (1997), pp. 160-61 y 163.

96. La época mercantilista: historia de la organización y las ideas económicas desde el final de la Edad Media hasta la sociedad liberal, traducción de Wenceslao Roces, México, Fondo de Cultura Económica, 1983, pp. 3-13 y 459-69.

97. Según Jaramillo Cervilla (Personalidad y pensamiento politico de Quevedo, Granada: Diputación Provincial, 1981, p.109), «participa del crisohedonismo y bullonismo que tradicionalmente se ha achacado a la práctica mercantilista española de la época [...] Sin embargo, en otro momento, expresa clarísimamente una concepción global de la economía, sorprendentemente, dentro de la más estricta ortodoxia mercantilista». Opiniones análogas 


\section{LA CONSTRUCCIÓN CRÍTICA DE UN QUEVEDO REACCIONARIO}

vocablo necesitado de precisión en el tiempo) que vive en la Europa del siglo XVII. En este aspecto mantuvo un pensamiento plenamente coherente en España defendida ${ }^{98}$, en El chitón de las tarabillas, en el cuadro XXX de La Fortuna con seso y la hora de todos y, por supuesto, en los versos 70-100 de la Epistola satírica, no siempre bien leídos ${ }^{99}$. Su modesta contribución a esta doctrina, que hizo suya sin especial esfuerzo, consistió en adornarla con alguna reminiscencia clásica y rodearla de sentido moral, como cuando recordó a Juvenal (por ejemplo, sus sátiras XI, 117-27 y XIV, 270-71) para expresar su rechazo a los gastos suntuarios. Pensamiento, por otra parte, nada excepcional en la época. "¿Qué Indias para la Francia como la misma España?», escribió Gracián (El Criticón 2, 8), exponiendo un punto de vista similar, también recogido en actas de Cortes o escritos de arbitristas ${ }^{100}$.

Parece, pues, necesario eliminar una acepción inadecuada porque el tecnicismo económico «mercantilismo» es útil para explicar algunos aspectos del pensamiento de Quevedo, mercantilista a su modo cuando evoca a poetas e historiadores latinos que elogiaron la austeridad como medio de frenar la decadencia de Roma. Como tal, no pudo estar en contra ni del comercio, ni de la navegación, ni de los metales preciosos, sino de un uso de los mismos que no beneficiaba a Espańa en su pugna con otras naciones. Naturalmente, esta afirmación no implica caer en el extremo opuesto y convertir a Quevedo en el paladín de la burguesía que nunca fue.

La imprecisión en torno al concepto de mercantilismo obliga a referirse a otros en los que también podrían haberse producido empleos inadecuados.

en Manuel Urí, «Crisis y arbitrismo: Quevedo y el pensamiento económico español del siglo de Oro", La Perinola, 2 (1998), pp. 263-300.

98. «Las mujeres inventaron excesivo gasto a su adorno y, así, la hacienda de la república sirve a su vanidad. Y su hermosura es tan costosa y de tanto daño a España que sus galas nos han puesto necesidad de naciones extranjeras, para comprar a precio de oro y plata galas y bujerías, a quien sola su locura y devaneo pone precio; de suerte que nos dejan los extranjeros el reino lleno de sartas y invenciones y cambray y hilos y dijes, y se llevan el dinero todo, que es el nervio y sustancia del reino» (España defendida, edición de Robert S. Rose, 1916, p. 85).

99. Como excepción véase Ramón Carande, Carlos Vy sus banqueros, I. La vida económica en Castilla, Barcelona, Crítica, 1990, p. 264.

100. Me baso en la nota 404 de la edición de Jean Bourg, Pierre Dupont y Pierre Geneste, Madrid, Cátedra, 1987, p. 274. Noticias sobre los mercaderes franceses que acudían a España pueden verse en Herrero García, Ideas de los españoles del siglo XVII, Madrid, Gredos, 1966, pp. 385 y ss. 
BULLETIN HISPANIQUE

\section{Providencialismo}

Frente a [las políticas de Olivares y Richelieu] opone Quevedo el providencialismo que iluminó los mejores años de los Habsburgos y que, a estas alturas del siglo XVII, tiene un matiz ciertamente reaccionario. El ambiente en el que surge la Execración está marcado por esta lucha ideológica soterrada entre dos formas de entender el Estado: la razón política y el mercantilismo, por un lado; y el providencialismo que propugna Quevedo, por otro ${ }^{101}$.

Como en el caso del mercantilismo, la palabra providencialismo, desplazada de su significado auténtico, cobra un matiz valorativo que no le corresponde. Stricto sensu el providencialismo político es la doctrina de, entre otros, Lipsio, Botero, Ribadeneira, Saavedra Fajardo y, en buena medida, los países contrarreformistas. No se debe creer que éstos constituían un bando retrógrado frente al supuesto progresismo maquiavélico, pues la polémica se planteó en otros términos: mientras Maquiavelo concedía un papel preponderante a la fortuna, cuyos designios se podían conocer $y$, hasta cierto punto, controlar, por medio de la virtud, los seguidores de Lipsio y Botero ponían en su lugar la providencia divina, al tiempo que trataban de persuadir que el respeto a la moral era la mejor garantía de éxito político, haciendo con ello gala de un notable casuismo pragmático ${ }^{102}$.

Más allá del ámbito político, la cuestión de la providencia mereció la atención de Quevedo en muchas obras, no siempre coincidentes entre sí: Política de Dios, La Fortuna con seso, Homilia de la Santísima Trinidad, La caída para levantarse y Marco Bruto. En el párrafo final de Providencia de Dios prometió una continuación donde mostraría la intervención de la providencia en la historia de Roma, desde la República hasta la Iglesia católica, pero nada podemos decir acerca de algo que, probablemente, no fue escrito. Se asemeja a tal proyecto la silva «Esta que miras grande Roma agora», donde no hay rastro de la intervención de Dios en la historia de esa nación. Tal vez Quevedo intentó una vía distinta a la de Campanella, tan apologética, sin haber logrado plenamente su objetivo ${ }^{103}$. Avanzado el siglo

101. Fernando Cabo Aseguinolaza y Santiago Fernández Mosquera, ed. de Execración contra los judios, Barcelona, Crítica, 1996, p. XXXIII.

102. Una información general sobre este problema ofrece Robert Bireley, The CounterReformation Prince, Chapel Hill and London, University of North Carolina, 1990.

103. Interesa recoger aquí el comentario del obispo de León a propósito de Providencia de Dios: «La resolución que vuesa merced ha tomado de probar con ejemplos la divina 
XIX todo un Hegel, lamentando la incapacidad de los cristianos para ver la presencia de la Providencia más allá del mundo natural o de los pequeños asuntos, se esforzó por «vouloir connaître et honorer Dieu en toutes choses, et en premier lieu dans l'histoire» ${ }^{104}$. Alguna similitud con el intento hegeliano tiene el de Quevedo en la citada Providencia de Dios. Según Juan Valera, dicha obra "presiente y predispone la filosofía por venir», hasta el punto de que el pleno desarrollo de su doctrina «hubiera producido una filosofía tan trascendental como la que en Descartes tuvo origen» ${ }^{105}$; según Borges, el poema "Cerrar podrá mis ojos la postrera» demostraba la inmortalidad del alma mejor que el mencionado tratado ${ }^{106}$. Entre la admiración de uno y la ironía de otro tal vez se pueda encontrar un término medio. En cualquier caso, la compleja cuestión política, moral y religiosa del providencialismo en la Europa del siglo XVII no es explicable desde las emociones de hoy. Porque cuando Quevedo atribuye a la permisión o designio de la Providencia determinados hechos (pecados, castigos, naufragios, incendios) se limita a la misma combinación de creencia rutinaria y manipulación interesada en que incurre, por ejemplo, el rey de Francia cuando agradece a Dios que una borrasca hubiese hundido los barcos españoles. También es posible que se hubiese dejado llevar de los sentimientos del momento González de Amezúa cuando celebró en Quevedo su «visión de la patria común, de la solidaridad nacional, de España como una comunión colectiva, a la que Dios ha encomendado una misión altísima» ${ }^{107}$. Es discutible que Quevedo, siempre pesimista a la hora de analizar la situación de España en Europa, hubiese participado de tal confianza. Por otra parte, el ardor y el tipo de argumentos

Providencia ha sido muy importante para convencer por todos caminos el fin del discurso; que cuando no fuera documento de tan gran santo como San Agustín, la experiencia enseña que mueven más fuertemente los ejemplos que las razones» (Epistolario completo, edición de Astrana Marín, Madrid, Reus, 1946, p. 448). Sobre la escéptica actitud de Quevedo en la páginas iniciales de La Fortuna con seso he sugerido en otro lugar (Obras completas de Quevedo, Madrid, Castalia, 2003, I, pp. XXXVI-XXXVII) que ni Dios, ni la Fortuna ni la Ocasión intervienen en el laberinto europeo que describió. La llegada al poder de la reina Isabel fue presentada por Hernando del Pulgar de un modo muy diferente a lo que hizo Quevedo respecto a Felipe IV en Grandes anales de quince días, lo que permitiría medir la distancia entre un providencialista y un escritor menos convencido al respecto. Análogamente, se podrían contrastar la piadosa crónica que Diego de Valera hace de los Reyes Católicos y las burlas de Quevedo al pietismo de Felipe III.

104. La raison dans l'histoire, traducción y notas de Kostas Papaioannou, Paris, 10/18, 1965 , p. 61.

105. Obras completas, Madrid, Aguilar, p. 1437 para ambas citas.

106. Inquisiciones, p. 45.

107. «Las almas de Quevedo», en Opúsculos histórico-literarios, Madrid, CSIC, 1951, I, p. 414. 
con que quiso demostrar la existencia de la Providencia sugieren que en los planos filosófico y teológico tampoco contó una firme certidumbre. Probablemente se necesita un estudio algo demorado del providencialismo en Quevedo, aunque sus escritos carezcan de novedad conceptual.

\section{Burguesía, TrABAJO, DINERO}

Suelen citarse los Sueños y el Buscón como prueba de la mentalidad antiburguesa de Quevedo, que se complace en caricaturizar los oficios humildes. El título de la primera obra advierte paladinamente que es una crítica de los «abusos, vicios y engaños en todos los oficios y estados del mundo", de modo que se critica al sastre no por serlo, sino porque roba, o al tabernero porque echa agua al vino, no por su condición de tal. Algo parecido se podría decir de la segunda: Historia de la vida del Buscón, llamado don Pablos, ejemplo de vagamundos y espejo de tacaños. En su galería de personajes no hay representantes del comercio, la agricultura o la industria. En la venta de Viveros (capítulo 1, 4) se nos habla de «un viejo mercader y avariento, procurando olvidarse de cenar»; más que un representante del mundo del dinero, es uno de esos tacaños enfermizos que tanto satiriza Quevedo. Más adelante se critica acerbamente a un banquero genovés por ser «anticristo de las monedas de España», con lo cual queda en claro que es bueno el dinero, y malo que lo lleven fuera. No encontramos los mercaderes del Guzmán de Alfarache, ni un caballero del Verde Gabán, ni uno de los campesinos acomodados del teatro de Lope de Vega, pese a que la acción transcurre por donde concurrían las clases medias urbanas y rurales. Tampoco se ocupa Quevedo de los oficios humildes: sastres, zapateros, carpinteros, herreros, tejedores, tundidores, curtidores, jornaleros, obreros y labradores (como excepción, los venteros, pero por moriscos y ladrones). También me parece significativo que siendo el Buscón una obra violentamente antijudía, no aparezcan judíos financieros, letrados, burócratas o médicos sino Diego Coronel, el impreciso Poncio de Aguirre y la poco refinada Ana Moráez. El mundo de la "clase media» y el trabajo sale indemne del Buscón, cuya crítica social apunta a los parásitos y mentirosos que pretenden vivir sin trabajar (arbitristas, ciegos de romances, malos poetas, malos comediantes, falsos mendigos, mujeres busconas, caballeros ociosos, etc.).

En este punto conviene recordar la Epistola satírica y censoria, versos 130132:

Hoy desprecia el honor al que trabaja, y entonces fue el trabajo ejecutoria y el vicio gradüó la gente baja. 
Parece que trabajo debe entenderse aquí como 'oficio mecánico', el cual no tenía que ser estrictamente manual ${ }^{108}$. En cuyo caso Quevedo compartiría las ideas favorables a su dignificación ${ }^{109}$, oponiéndose a nocivos prejuicios señoriales, igualmente condenados por Venegas ${ }^{110}$, enemigo de la ociosidad perniciosa ( $\mathrm{El}$ segundo vicio es que en sola España se tiene por deshonra el oficio mecánico, por cuya causa hay abundancia de holgazanes y malas mujeres»), y por González de Cellorigo ${ }^{111}$. No se puede negar que en el Buscón hay, también, una crítica contra los que no trabajan, y en tal sentido es vinculable también a esa corriente de escritos que desde Luis Vives se ocupó de los problemas relacionados con la mendicidad y el trabajo.

Desde el punto de vista económico, el objetivo de Quevedo es el fortalecimiento de la Monarquía española, la obtención de una balanza de pagos favorable, no el bienestar entendido como incremento del consumo y reparto de bienes. Nada impide, a quien lo desee, juzgar sus escasas reflexiones económicas a la luz de la lucha de clases, pero tal análisis debería tener en cuenta observaciones como las anteriores. Por otra parte, algunas exégesis interpretan las numerosas invectivas de Quevedo contra la codicia y el oro como ataques contra la clase emergente que amenaza al estamento noble, pero cualquier manual de historia relata la complicidad entre aristocracia y burguesía que se dio en Europa durante la Edad Moderna. Maravall se sorprendía del error: "¿Cómo van a estar estas críticas y condenaciones inspiradas por los nobles si entre la nobleza se encuentran por excelencia los ricos? ${ }^{112}$. No es seguro que cuando Quevedo zahiere reiteradamente a ricos y poderosos en Virtud militante, Las cuatro fantasmas, Doctrina moral y varios poemas morales tenga en mente una categoría social determinada; pero si se desea concretarla en la sociedad del momento, habrá que hacerlo en los nobles.

108. De modo diferente, Lía Schwartz e Ignacio Arellano ven una referencia al «trabajo de la nobleza contemporánea al autor» (Un Heráclito cristiano, Canta sola a Lisi y otros poemas, Barcelona, Crítica, 1998, p. 79), en tanto que Díez Fernández («La Epistola satírica y censoria», p. 61) sugiere «desempeño de las obligaciones militares». Sobre una definición de esta palabra como sinónimo de 'trabajo mecánico', véase José Antonio Maravall, Teatro y literatura en la sociedad barroca, Barcelona, Crítica, 1990, pp. 128-33.

109. Recuérdese su silva «Tú, si en cuerpo pequeño», en defensa de la pintura, actividad considerada no liberal.

110. Agonía del tránsito de la muerte, edición de José Pérez de Ayala, Madrid, Instituto de Cooperación Iberoamericana, 1991, p. 174.

111. Memorial de la política necesaria, pp. 50 y 79.

112. «Sobre el pensamiento social y político de Quevedo», p. 87. 


\section{LA RELACIÓN CON OLIVARES}

Para John H. Elliott, la desafección de Quevedo hacia Olivares, a quien antańo había apoyado, tuvo lugar entre 1634 y 1636, siendo un claro indicio el soneto dedicado a don Fadrique de Toledo ("Al bastón que le vistes en la mano»), muerto en $1634^{113}$. Bourg, Dupont y Geneste adelantan la ruptura hacia $1633^{114}$, lo mismo que Cabo y Fernández Mosquera ${ }^{115}$, en tanto que $\mathrm{Uri}^{\prime 16}$ la hace retroceder a 1630. La tesis de un Quevedo opuesto a cualquier cambio se ve reforzada por la eventualidad de que, en su hostilidad al valido modernizador, hubiese terminado aliándose con la nobleza para contribuir a su caída. Según Elliott, "el impulso reformista había desaparecido del gobierno, y el poder era compartido por grupos aristocráticos rivales y una jerarquía de letrados que gobernaba mediante las instituciones consiliares tradicionales. El carácter global de este sistema de poder compartido era tal que satisfacía los intereses de los poderosos. En esencia, 1643 les había dado lo que querían, y las fuerzas de la contrarrevolución habían ganado» ${ }^{117}$. Quevedo, según algunas opiniones de hoy, formaría parte de tales fuerzas.

Probablemente su actitud hacia Olivares consistió en algo más irregular que en una evolución desde el aprecio al odio, pues lo aplaudió y atacó a lo largo de su vida, en una oscilación dictada por sus circunstancias personales y por los específicos problemas políticos de cada momento. Lo elogió en la primera redacción de Grandes anales de quince días (hacia 1621) ${ }^{118}$, pero en la segunda y tercera (entre 1624 y 1635 ) atemperó las alabanzas ${ }^{119}$. Aplaudió en El chitón de las tarabillas (1630) algunas de sus medidas financieras sin, posiblemente, dejar de criticar otras. También lo apoyó en La rebelión de Barcelona y en Respuesta al duque de Berganza, aunque en ésta le recriminó su falta de perspicacia para evitar la difusión de un escrito favorable a los rebeldes

113. "Quevedo and the Count-Duke of Olivares", en Quevedo in Perspective, edición de James Iffland, Newark, Delaware, Juan de la Cuesta, 1982, pp. 243-44.

114. Edición de La hora de todos y la fortuna con seso, pp. 69-88.

115. Francisco de Quevedo, Execración contra los judios, pp. XI-XII.

116. Francisco de Quevedo, El chitón de las tarabillas, p. 18.

117. «Una sociedad no revolucionaria: Castilla en la década de 1640», en 1640: La monarquia hispánica en crisis, Barcelona, Centre d'Estudis d' Historia Moderna «Pierre Vilar»-Crítica, 1992, p. 120.

118. Aunque también narró en términos que parecen poco favorables la interesada petición que quiso hacer llegar a Felipe III en su lecho de muerte. Cfr. Grandes anales de quince días, edición de Victoriano Roncero, en Quevedo. Obras completas en prosa, Madrid, Castalia, 2005, III, p. 62.

119. Así lo expuso Roncero en la edición mencionada en la nota anterior, pp. 45-49. 


\section{LA CONSTRUCCIÓN CRÍTICA DE UN QUEVEDO REACCIONARIO}

portugueses. En la cuestión de copatronazgo de santa Teresa mantuvo una actitud más bien desafiante: en una carta de 5 de mayo de 1626 dirigida al Conde-Duque y en otra enviada a Pellicer el 8 de mayo ${ }^{120}$ afirmó no querer imprimir Su espada por Santiago para no contrariar al valido, pese a lo cual sufrió una nueva orden de destierro, tal vez por haber insistido en sus puntos de vista ante el papa Urbano VIII. Su decidida actitud en este pleito santiaguista, enfrentándose al valido y, probablemente, al monarca, más o menos por la misma época en que había escrito su primera versión de la Epistola satírica y censoria (1625) y remodelado la comedia Cómo ha de ser el privado, pone de relieve los altibajos de una relación ${ }^{121}$. Conviene recordar, también, que la mencionada Epistola satírica y censoria la leemos en una versión final tal vez posterior a la caída de Olivares. Cuando Quevedo estaba preparando la edición de su poesía completa tuvo que decidir si seguía elogiando a quien ya había desaparecido o si descartaba tales versos, y se inclinó por la primera opción ${ }^{122}$. Tampoco deben seguir en la penumbra dos manifestaciones merecedoras de atención. La primera pertenece al final del Panegírico a Felipe $I V$ : tras acusar a Olivares de haber establecido excesivos gravámenes, de haber alejado al monarca de los súbditos y de haber actuado erróneamente en la cuestión catalana, Quevedo concluye exculpándolo, como si tales desaciertos no pudiesen anular una labor laudable en sus aspectos generales:

El apartar semejantes personas no presupone culpa suya, siempre suele ser conveniencia forzosa, y no sólo puede haber inocencia en el que apartan, sino en el que justician. Conviene que uno muera por

120. Véase Luis Iglesias Feijoo, «Una carta inédita de Quevedo y algunas noticias sobre los comentaristas de Góngora, con Pellicer al fondo", Boletin de la Biblioteca de Menéndez Pelayo, 59 (1983), pp. 197-98.

121. Inversamente a lo que sucedió en Grandes anales de quince días, en La caída para levantarse mitigó una alusión crítica hacia el privado. Según Valentina Nider («Nerón y el arquitecto. Sobre una variante manuscrita acerca de la caída de Olivares», en Quevedo en Manhattan, edición de Ignacio Arellano y Victoriano Roncero López, Madrid, Visor, 2004, p. 198), Quevedo «prefiere dejar de lado toda mención polémica a Olivares, definitivamente destronado [...] olvidando piadosamente el destino de un hombre al que siempre reconoció cierta grandeza».

122. Recuérdense las dos versiones del poema «Si los trofeos al túmulo debidos», dedicada una a Luis Carrillo y otra a Bernardino de Mendoza, así como los poemas «Miré ligera nave» y «Estando solo un día», versiones variantes, acomodada una a la memoria de Carrillo y otra a la de un tal don Juan. También en las obras en prosa se detectan algunos cambios de mención y dedicatoria. Para Quevedo habría resultado muy sencillo mantener lo esencial de la Epistola satírica y censoria tras haber eliminado cualquier referencia elogiosa al valido. 
el pueblo porque toda la gente no perezca ${ }^{123}$. Costó la vida al hijo de Dios, y fue proposición que aun en muerte tan injusta mereció nombre de profecía. No ha pronunciado jamás la ignorancia trágica, ni la locura furiosa, ni la malignidad detestable, que conviene que el pueblo y toda la gente muera porque uno solo no perezca; pues si por alguno había de poder proponerse, era solamente por el Señor que se dijo convenía que muriese porque no pereciese toda la gente.

La segunda es una carta enviada al padre Pedro de Pimentel el 4 de febrero de 1643 , sobre la cual conviene volver a llamar la atención ${ }^{124}$.

Mas como el rey nuestro señor nos ha trocado el siglo de hierro en buena moneda y, con tan esclarecida liberalidad, nos hace ańos de oro, es deuda mostrar regocijo. Ya que el contar cuentos es la tarabilla de los viejos, yo, que soy el cuento de los cuentos y estoy de la otra parte de decrépito, quiero caducar, como es uso y costumbre.

Escribió el arzobispo de Toledo ${ }^{125}$ en tiempo de los Reyes Católicos (perdóneme vuestra reverendísima el "érase que se era», que es la empuñadura de las consejas) a Hernando del Pulgar carta que anda impresa entre las suyas con los Varones ilustres que le avisase cómo corrían las cosas del gobierno. Respondiole que «la reina era el privado del rey y el rey de la reina el privado, y que con esto decía que no podían ir mejor». Si fuese a propósito, no es mal chiste. Quiero que esto ande con buenas compañías y autorizar esto.

123. Evocación de las palabras de Caifás (Juan 11,50) profetizando la muerte de Jesús.

124. Reproduzco la transcripción que ofrecí en Obras completas de Quevedo en prosa, Madrid, Castalia, 2005, III, pp. LXIII-LXIV. Algo diferentes, con algunas modificaciones en ortografía, acentuación y puntuación, son las versiones de Astrana Marín en Epistolario completo de don Francisco de Quevedo, pp. 451-52, y de James O. Crosby (Nuevas cartas de la última prisión, Londres, Támesis, 2005, pp. 118-20). Jauralde (Francisco de Quevedo, 1580-1645, pp. 810-11) la transcribió parcialmente, con una valoración diferente a la aquí propuesta.

125. Más exactamente, el canónigo de Sevilla, Pedro de Toledo. Hernando del Pulgar consideró beneficiosa la ausencia de un valido de los Reyes Católicos. Quevedo parece aludir, también, a la respuesta de Felipe IV a sor María de Ágreda cuando ésta le preguntó por el nuevo valido: «mi privado es la reina». R. A. Stradling comentó esa afirmación a propósito de la intervención de la reina en la caída de Olivares. Véase Felipe IV y el gobierno de España, 1621-1665, traducción de Carlos Laguna, Madrid, Cátedra, 1989, pp. 354-55 y 474. 


\section{LA CONSTRUCCIÓN CRÍTICA DE UN QUEVEDO REACCIONARIO}

Acuérdome que en el primer libro de los Reyes, cap. 29, v. 6 (esto va de majestad y ninguna corona podrá extrańarlo) se lee ${ }^{126}$ : «Vocabit ergo Achis David et ait ei: vivit Dominus, quia rectus es tu, et bonus in conspectu meo: et exitus tuus, et introitus tuus mecum est in castris, et non inveni in te quidquam mali ex die qua venisti ad me usque in diem hanc; sed satrapis non places. Revertere ergo, et vade in pace, et non offendas oculos satraparum Philisthiim». Replicó David que en qué le había deservido y desagradado después que le asistía. Respondiole Achis: «Scio quia bonus es tu in oculis meis, sicut angelus Dei; sed principes Philisthinorum dixerunt: non ascendet nobiscum in praelium. Igitur consurge mane tu, et servi domini tui, qui venerunt tecum, et cum de nocte surrexeritis, et coeperit dilucescere, et pergite».

Canas tiene, reverendísimo padre, el decir los reyes requiebros al que echan y despiden, y repare el que, a la réplica de David, añade más requiebro llamándole «ángel de Dios» y juntamente más priesa en la partida suya, señalándole día y hora y añadiendo que no quede ninguno de los que vinieron con él. Sea contrapunto: pues si al recto y al bueno siempre y que era como un ángel de Dios, le despiden sólo porque no agrada a los sátrapas, luego... Aquí se acaba la lógica. Vuestra reverendísima sacará la consecuencia, que se me huye.

Perdone vuestra reverendísima que el idiota coplero profane estas cosas, y dé Dios a vuestra reverendísima la vida que yo le deseo.

126. I Samuel 29, 6-10, según la ordenación de la Vulgata. Reproduzco la traducción de E. Nácar y A. Colunga: «Aquis llamó a David y le dijo: "Como vive Yavé, que tú eres hombre leal y que yo veo con buenos ojos toda tu conducta en esta expedición, sin haber visto en ti nada malo desde que llegaste a mí hasta hoy; pero a los príncipes no les agradas. Vuélvete, pues, y torna en paz, para no desagradar a los príncipes de los filisteos". David respondió: "Pero, ¿qué he hecho yo y qué has hallado tú en tu siervo, desde que estoy junto a ti hasta hoy, para que no marche yo a combatir a los enemigos de mi señor, el rey?". Aquis respondió: "Yo sé bien que tú has sido bueno conmigo, como un ángel de Dios; pero los jefes de los filisteos dicen: Que no suba con nosotros a la batalla. Así que levántate de mañana tú y los siervos de tu señor que han venido contigo; iréis al lugar que os he señalado; no guardes resentimiento en tu corazón, porque me eres grato"». 
Además de rescatar del olvido estos datos, es preciso resolver otros problemas de datación ${ }^{127}$, autoría ${ }^{128}$ y explicación de textos ${ }^{129}$, amén de abordar el confuso episodio de la prisión en San $\operatorname{Marcos}^{130}$. De lo contrario se corre el riesgo de interpretar políticamente unos hechos que no se sabe bien cómo se desarrollaron. No es fácil emitir un rápido juicio acerca de la actitud de Quevedo hacia Olivares, entre otros motivos a causa de sus contradictorias personalidades.

\section{Conclusión}

Los parcos testimonios conservados indican que durante el siglo XVII Quevedo fue considerado un escritor irreverente en materia religiosa, crítico con los gobernantes y moralizador, siendo esta tercera faceta la más destacada durante los siglos XVIII y XIX, a la cual añadió el Romanticismo la visión de un luchador contra el despotismo y la decadencia de España. Durante los dos primeros tercios del siglo XX siguió prevaleciendo la imagen de un moralista estoico y cristiano, pero en el último cuarto del siglo cobró fuerza la visión de Quevedo como un propagador de lo que Marx y Engels llamaban ideología, es decir, falacias que tratan de justificar o de enmascarar el dominio de la oligarquía. Esta moderna interpretación, sin haber alcanzado unanimidad, parece contar con un estimable seguimiento, pero necesita refinarse como tendencia hermenéutica. En el aspecto filológico debe esmerarse por entender las palabras y expresiones de Quevedo en su contexto literario y cultural, mostrándose más precavida con los cambios semánticos que experimentaron desde entonces; en el aspecto historiográfico, debe

127. No es baladí la fecha de la Epistola satírica y censoria, en torno a la cual se hacen girar algunas interpretaciones de la ideología de Quevedo. Las cuatro redacciones conocidas sugieren que hubo un proceso de revisiones que podría haber comenzado en 1625 y concluir en torno a 1645. Información sobre el texto y versiones de esta obra puede verse en Alfonso Rey edición de Poesía moral. Polimnia, Madrid: Támesis, 1999, pp. 139 y 347.

128. Por ejemplo, Crosby, en Nuevas cartas de la última prisión de Quevedo, pp. 51-56, considera que el memorial al Conde-Duque que comienza "Si no es la esperanza...» está erróneamente atribuido a Quevedo.

129. Así sucede con la enigmática carta de 28 de enero de 1643 dirigida al padre Pedro Pimentel, que Crosby (Nuevas cartas, pp. 118 y 264-68) interpreta como una alusión a la caída del Conde-Duque.

130. En la dedicatoria a Juan Chumacero Carrillo de La caída para levantarse (edición de Valentina Nider, Pisa, Giardini, 1994, p. 126), Quevedo afirma que «nunca se me hizo cargo, ni tomó confesión» en lo relacionado con su detención. Parece insólito que tras haberlo arrestado por participar en un posible complot, la autoridad responsable no hubiese mostrado el menor interés en obtener información del conspirador. 
manejar con más precisión las nociones políticas y económicas que suelen emplear los historiadores profesionales ${ }^{131}$. Séneca, en la epístola mencionada al comienzo de este artículo, mencionó con alguna ironía el modo en que filósofos, filólogos y gramáticos abordaban un mismo texto. Recordando sus comentarios, aunque sin la preocupación moral que él hacía prevalecer sobre otras consideraciones, se podría decir que en la interpretación del pensamiento de Quevedo no ha habido el necesario equilibrio entre filósofos y filólogos.

131. Una propuesta para otra lectura de Quevedo, al margen del romanticismo y del «materialismo histórico», puede verse en los prólogos de los volúmenes I-V de Quevedo. Obras completas en prosa, Madrid, Castalia, 2003, 2005, 2006, 2010 y 2011. 